\title{
Comparison of 2 protocols to increase circulating progesterone concentration before timed artificial insemination in lactating dairy cows with or without elevated body temperature
}

\author{
M. H. C. Pereira, ${ }^{*}$ M. C. Wiltbank, † T. G. Guida, ${ }^{*}$ F. R. Lopes Jr., ${ }^{*}$ and J. L. M. Vasconcelos $\ddagger^{1}$ \\ ${ }^{*}$ Faculdade de Medicina Veterinária e Zootecnia, Universidade Estadual Paulista (UNESP), Botucatu, SP 18618-000, Brazil \\ †Department of Dairy Science, University of Wisconsin, Madison 53706 \\ ‡Department of Animal Production, São Paulo State University, Botucatu, SP 18168-000, Brazil
}

\begin{abstract}
Two treatments designed to increase circulating progesterone concentration (P4) during preovulatory follicle development were compared. One treatment used 2 intravaginal P4 implants (controlled internal drug-releasing inserts; CIDR) and the other used a GnRH treatment at beginning of the protocol. Lactating Holstein cows that had been diagnosed as nonpregnant were randomly assigned to receive timed artificial insemination (TAI) following 1 of 2 treatments ( $\mathrm{n}=$ 1,638 breedings): (1) GnRH: CIDR $+2 \mathrm{mg}$ of estradiol (E2) benzoate $+100 \mu \mathrm{g}$ of $\mathrm{GnRH}$ on $\mathrm{d}-11, \mathrm{PGF}_{2 \alpha}$ on $\mathrm{d}-4$, CIDR withdrawal $+1.0 \mathrm{mg}$ of E2-cypionate + $\mathrm{PGF}_{2 \alpha}$ ) on $\mathrm{d}-2$, and TAI on d 0; or (2) 2CIDR: 2 CIDR $+2 \mathrm{mg}$ of E2-benzoate on $\mathrm{d}-11,1$ CIDR withdrawn + $\mathrm{PGF}_{2 \alpha}$ on $\mathrm{d}-4$, second CIDR withdrawn $+1.0 \mathrm{mg}$ of E2-cypionate $+\mathrm{PGF}_{2 \alpha}$ on $\mathrm{d}-2$, and TAI on $\mathrm{d} 0$. Milk yield was measured daily between d 0 and $\mathrm{d} 7$. Rectal temperature was measured using a digital thermometer at $\mathrm{d} 0$ and 7 , and elevated body temperature was defined as an average rectal temperature $\geq 39.1^{\circ} \mathrm{C}$. Pregnancy diagnoses were performed on d 32 and 60 after TAI. We detected no effect of treatments on pregnancy per AI or pregnancy loss regardless of elevated body temperature, body condition score, parity, milk yield, or presence or absence of a corpus luteum (CL) on $\mathrm{d}-11$ or $\mathrm{d}-4$. Pregnancy per AI at $60 \mathrm{~d}$ was reduced [elevated body temperature $=22.8 \%(162 / 709)$, no elevated body temperature $34.1 \%(279 / 817)$ ] and pregnancy loss tended to increase [elevated body temperature $=20.2 \%(41 / 203)$, no elevated body temperature $14.4 \%(47 / 326)$ ] in cows with elevated body temperature. Various physiological measurements associated with greater fertility were also reduced in cows with elevated body temperature, such as percentage of cows with a CL at $\mathrm{PGF}_{2 \alpha}$ (de-
\end{abstract}

Received October 12, 2016.

Accepted June 8, 2017.

${ }^{1}$ Corresponding author: vasconcelos@fmvz.unesp.br creased 7.9\%), ovulatory follicle diameter (decreased $0.51 \mathrm{~mm}$ ), expression of estrus (decreased $5.1 \%$ ), and ovulation near TAI (decreased 2.8\%) compared with cows without elevated body temperature. A greater proportion of cows $(30.2 \%)$ had a CL at $\mathrm{PGF}_{2 \alpha}$ in the GnRH treatment $[74.1 \%(570 / 763)]$ than in the 2CIDR treatment $[56.9 \%(434 / 763)]$; however, circulating P4 concentration was greater at the time of $\mathrm{PGF}_{2 \alpha}$ treatment $(\mathrm{d}-4)$ for cows 2 CIDR $(4.26 \pm 0.13 \mathrm{ng} / \mathrm{mL})$ than in cows in $\mathrm{GnRH}(3.99 \pm 0.14 \mathrm{ng} / \mathrm{mL})$. Thus, these 2 protocols yield similar fertility results that might be due to somewhat different physiological alterations. Treatment with GnRH increased the proportion of cows with a CL at $\mathrm{PGF}_{2 \alpha}$; however, the $2 \mathrm{CIDR}$ protocol increased circulating $\mathrm{P} 4$ under all circumstances.

Key words: synchronization protocols, progesterone, elevated body temperature

\section{INTRODUCTION}

Elevated progesterone (P4) during preovulatory follicle development is associated with greater fertility in cows submitted to AI after natural estrus (Folman et al., 1973; Erb et al., 1976; Fonseca et al., 1983; Meisterling and Dailey, 1987), after $\mathrm{PGF}_{2 \alpha}$-induced luteolysis (Diskin et al., 2006) or during timed AI (TAI) protocols (Giordano et al., 2010; Martins et al., 2011). Some of the reasons for reduced circulating P4 concentrations during growth of the preovulatory follicle in TAI protocols can be lack of a corpus luteum $(\mathbf{C L})$ at the beginning of a synchronization protocol for first AI (Stevenson et al., 2008; Bisinotto et al., 2010a, 2013) or subsequent AI services (Fricke et al., 2003; Sterry et al., 2006; Silva et al., 2009), elevated steroid metabolism in lactating dairy cows (Sangsritavong et al., 2002; Vasconcelos et al., 2003; Wiltbank et al., 2006), or regression of the CL during the protocol (Thatcher et al., 1986; Araujo et al., 2009; Monteiro et al., 2015). Thus, lactating dairy cows can have reduced circulating P4 concentrations during preovulatory follicular devel- 
opment during natural or synchronized cycles, resulting in reduced pregnancy per AI (P/AI; Souza et al., 2008; Bisinotto et al., 2010a,b, 2013; Denicol et al., 2012; Dirandeh et al., 2015a,b; Wiltbank et al., 2015).

Two different approaches have been used to increase circulating P4 during preovulatory follicle development. First, treatment with GnRH at the beginning of a protocol can ovulate a follicle, even in the presence of a primary $\mathrm{CL}$, thereby increasing circulating $\mathrm{P} 4$ by creation of an accessory CL. As expected, in GnRH-based protocols, increased circulating $\mathrm{P} 4$ concentration at the beginning of the protocol (Bisinotto et al., 2010b, 2013; Denicol et al., 2012) and the presence of a functional $\mathrm{CL}$ at the time of $\mathrm{PGF}_{2 \alpha}$ treatment have been associated with improved fertility (Giordano et al., 2010; Martins et al., 2011). Protocols that use GnRH on d 6 or 7 of the estrous cycle have a particularly high percentage of cows that ovulate to the $\mathrm{GnRH}$ treatment compared with cows treated with $\mathrm{GnRH}$ on other days of the cycle. This results in a new accessory CL, increased circulating $\mathrm{P} 4$, and better synchronization of the preovulatory follicular wave, resulting in increased $\mathrm{P} / \mathrm{AI}$ with these protocols (Vasconcelos et al., 1999; Souza et al., 2008; Herlihy et al., 2012; Dirandeh, 2014; Wiltbank and Pursley, 2014). Similarly, addition of GnRH at the beginning of estradiol (E2)- and P4-based protocols results in greater circulating $\mathrm{P} 4$ at $\mathrm{PGF}_{2 \alpha}$ and greater fertility with these protocols (Pereira et al., 2015). Increased P4 during E2- or P4-based protocols is particularly important because these protocols result in lower circulating $\mathrm{P} 4$ concentrations at the time of $\mathrm{PGF}_{2 \alpha}$ treatment $(2.29 \pm 0.15 \mathrm{ng} / \mathrm{mL})$ compared with GnRH protocols $(2.89 \pm 0.15 \mathrm{ng} / \mathrm{mL}$; Vasconcelos et al., 2011a). In addition, ovulation to GnRH at the beginning of a synchronization protocol initiates a new follicular wave and may therefore improve synchronization of the follicular wave and potentially improve fertility during a TAI protocol. A second method to increase circulating P4 during preovulatory follicle growth is by using a P4 implant such as a controlled internal drug-releasing insert (CIDR). However, lactating cows have greatly elevated metabolism of circulating $\mathrm{P} 4$ due to elevated liver blood flow and this results in a suboptimal increase in circulating $\mathrm{P} 4(<1 \mathrm{ng} / \mathrm{mL})$ during treatment with a single P4 implant (Stevenson et al., 2006). Alternatively, Bisinotto et al. (2013) evaluated supplementation of cows with low circulating $\mathrm{P} 4$ at the beginning of a protocol with 2 CIDR in a GnRH-based 5-d TAI program (d $-8 \mathrm{GnRH}, \mathrm{d}-3$ and $-2 \mathrm{PGF}_{2 \alpha}$, d 0 GnRH and AI). Treatment with 2 CIDR increased circulating $\mathrm{P} 4$ to $2.65 \mathrm{ng} / \mathrm{mL}$ and restored fertility in lactating dairy cows lacking a CL at the initiation of the TAI program to a value that was similar to cows that began the protocol with a CL, compared with cows with low circulating $\mathrm{P} 4$ without CIDR. In a recent study from our group (Pereira et al., 2017), we evaluated supplementation with 2 instead of 1 CIDR in an E2-/P4-based protocol in cows with reduced circulating $\mathrm{P} 4$ concentration at the beginning of the protocol $(<1.0$ $\mathrm{ng} / \mathrm{mL}$ ). Treatment with 2 CIDR tended to increase P/ AI compared with 1 CIDR in TAI (1 CIDR: $42.8 \%$ vs. 2 CIDR: $52.6 \% ; \mathrm{n}=326)$ but not in timed embryo transfer $(\mathrm{n}=445)$ programs. Thus, increased circulating $\mathrm{P} 4$ and improved P/AI have been shown for protocols that produce a new CL using GnRH treatment or directly increase circulating $\mathrm{P} 4$ by treating with $2 \mathrm{P} 4$ implants instead of 1 P4 implant during the protocol.

The objective of this study was to compare these 2 strategies for increasing circulating P4 concentration during preovulatory follicular development in lactating dairy cows. We hypothesized that treatment with GnRH or treatment with 2 CIDR would produce similar circulating $\mathrm{P} 4$ concentrations during the protocol, similar percentage of cows ovulating near TAI, and similar $\mathrm{P} / \mathrm{AI}$ and pregnancy losses in lactating dairy cows.

\section{MATERIALS AND METHODS}

This experiment was conducted at 4 commercial dairy farms in Minas Gerais State, Brazil, from May 2013 to January 2014. All animal procedures followed the recommendations of the Guide for the Care and Use of Agricultural Animals in Agricultural Research and Teaching (FASS, 1999). During the experimental period, cows were housed in freestall barns and had access to an adjoining sod-based paddock. Throughout the experiment, cows were milked 3 times daily. All procedures, including injections, ovarian ultrasonography, pregnancy diagnosis, blood collection, and TAI, were performed while cows were restrained in self-locking head gates at the feedline. Cows were fed ad libitum a TMR based on corn silage and Tifton hay as forages, with concentrates composed of corn and soybean meal, and added minerals and vitamins, which was balanced to meet or exceed the nutritional requirements of lactating dairy cows (NRC, 2001).

\section{Animals and Treatments}

This study used 1,638 breedings in lactating Holstein cows (throughout the text, "n" refers to the number of breeding events that received a particular protocol). At the beginning of the experiment $(\mathrm{d}-11)$, cows averaged $187.8 \pm 13.5$ DIM, yielding $31.4 \pm 2.23 \mathrm{~kg}$ of milk/d, BCS of $2.94 \pm 0.03$ [on a 1 (emaciated) to 5 (obese) scale; Wildman et al., 1982], lactation number of $2.43 \pm 0.36$ [primiparous $(=1) \mathrm{n}=457$; multiparous $(\geq 2) \mathrm{n}=1,181]$, and had been bred $3.38 \pm 0.08$ times. 
All cows were diagnosed nonpregnant before being enrolled in this trial. Within each farm, cows were divided in batches by parity (primiparous and multiparous), DIM, and milk production. All cows found to be not pregnant after a previous AI were randomized into the study, regardless of whether they had been previously utilized in the study. Cows received the following TAI protocol: an intravaginal $\mathrm{P} 4$ insert containing $1.9 \mathrm{~g}$ of P4 (CIDR, Zoetis, São Paulo, Brazil) and $2.0 \mathrm{mg}$ of estradiol benzoate (EB, i.m.; $2.0 \mathrm{~mL}$ of Estrogin, Farmavet, São Paulo, Brazil) on d $-11 ; 25$ mg (i.m.) of dinoprost tromethamine $\left(\mathrm{PGF}_{2 \alpha} ; 5.0 \mathrm{~mL}\right.$ of Lutalyse, Zoetis) on $\mathrm{d}-4$; CIDR withdrawal and $1.0 \mathrm{mg}$ (i.m.) of estradiol cypionate (ECP; $0.5 \mathrm{~mL}$ of E.C.P., Zoetis) and $\mathrm{PGF}_{2 \alpha}$ on $\mathrm{d}-2$; and TAI on $\mathrm{d} 0$. Cows were randomly assigned to receive 1 of 2 treatments (Figure 1 ): (1) GnRH treatment): $100 \mu \mathrm{g}$ of GnRH injection on d -11 (i.m.; $2.0 \mathrm{~mL}$ of Cystorelin, Merial, SP, Brazil) or (2) 2CIDR treatment): an additional CIDR placed on $\mathrm{d}-11$, which was removed at $\mathrm{d}-4$.

The TAI was performed (d 0) using commercial, frozen-thawed semen from 36 bulls. Devices for detection of estrus (Estrotect, Rockway Inc., Spring Valley, WI) were placed on the tail head of cows at the time of CIDR removal. The Estrotect patches were not used for detection of estrus or timing of AI because all cows were bred to TAI by study personnel during the experimental period. The Estrotect was monitored at TAI by the research personnel, and cows with an activated Estrotect (complete color change) were designated as expressing estrus during the protocol.

\section{Ultrasonography}

In both groups, ovaries were evaluated by transrectal ultrasonography (US, Aloka SSD-500 with a $7.5-\mathrm{MHz}$ linear-array transducer, Aloka, Tokyo, Japan) on d $-11,-4$ and 7 to determine presence of a CL (independent of its diameter), and at d 0 to measure the diameter of the largest follicle present. Ovulation at the beginning of the protocol was defined by the presence of a follicle $>8 \mathrm{~mm}$ on $\mathrm{d}-11$ and with a corresponding new $\mathrm{CL}$ at the time of first $\mathrm{PGF}_{2 \alpha}$ treatment $(\mathrm{d}-4)$. In addition, the percentage of cows with a new CL on $d$ -4 , independent of the presence of a follicle $>8 \mathrm{~mm}$ on $\mathrm{d}-11$, was also determined and used in some analyses. The size of the ovulatory follicle was determined by the largest follicle present on the ovary on $\mathrm{d} 0$ that corresponded to an observed CL on $\mathrm{d} 7$. Cows with follicles $<8 \mathrm{~mm}$ on $\mathrm{d} 0$ but with a CL on $\mathrm{d} 7$ were defined as "early ovulators" and were not used in analyses of ovulatory follicle diameters.

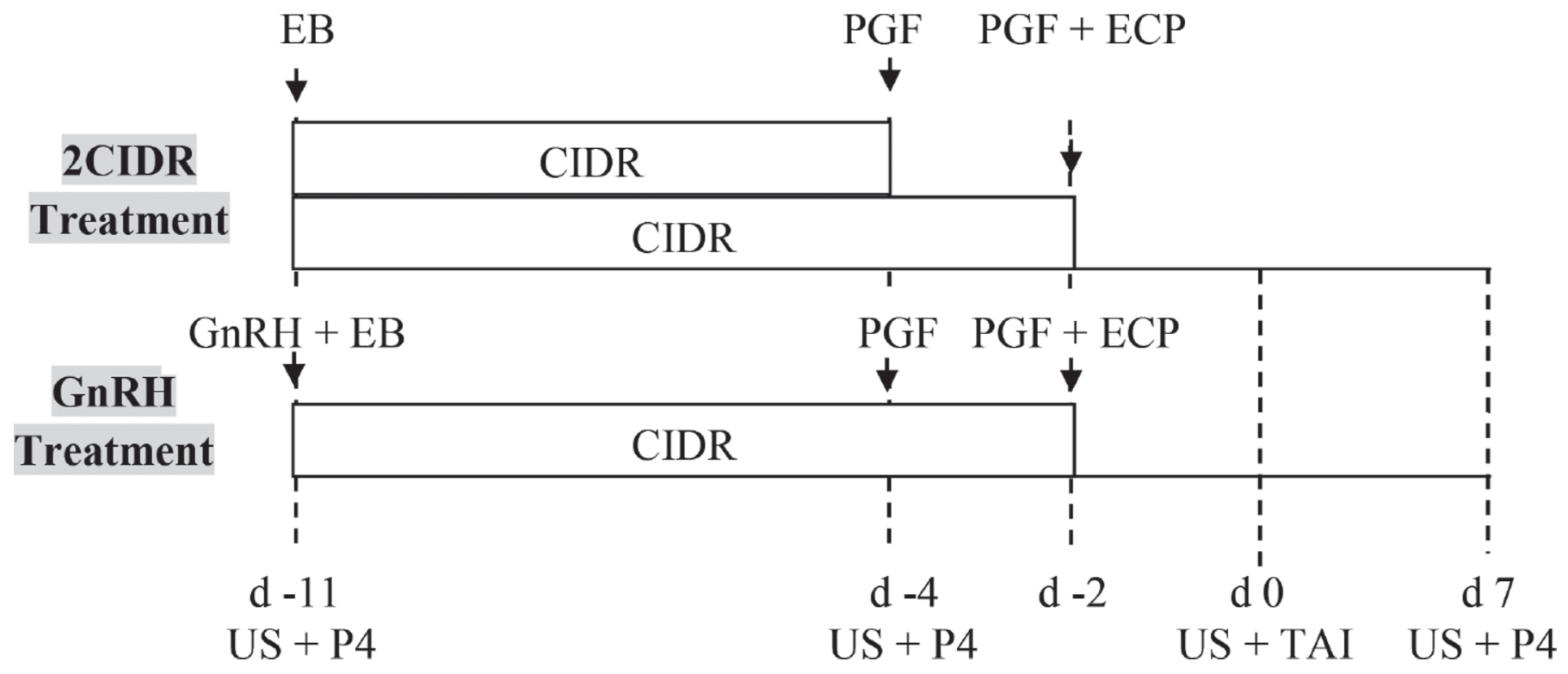

Figure 1. Diagram of activities. Ovaries were evaluated by ultrasound (US) in all cows on $d-11,-4,0$ and 7 . Cows received the following timed AI (TAI) protocol: an intravaginal progesterone (P4) insert containing $1.9 \mathrm{~g}$ of P4 (CIDR, Zoetis, São Paulo, Brazil) and 2.0 mg of estradiol benzoate (EB, i.m.; $2.0 \mathrm{~mL}$ of Estrogin, Farmavet, São Paulo, Brazil) on d -11; $25 \mathrm{mg}$ (i.m.) of dinoprost tromethamine (PGF ${ }_{2 \alpha}$; 5.0 $\mathrm{mL}$ of Lutalyse, Zoetis) on $\mathrm{d}-4$; CIDR withdrawal, $1.0 \mathrm{mg}$ (i.m.) of estradiol cypionate (ECP; $0.5 \mathrm{~mL}$ of ECP, Zoetis) and PGF $2 \alpha$ on d -2 ; and TAI on d 0. Cows were randomly assigned to receive 1 of 2 treatments: (1) GnRH treatment: 100- $\mu \mathrm{g}$ GnRH injection at d -11 (i.m.; $2.0 \mathrm{~mL}$ of Cystorelin, Merial, São Paulo, Brazil) or (2) 2CIDR treatment: an additional CIDR at d -11 , which was removed at d -4 . P4 $=$ blood sampling and analysis of $\mathrm{P} 4$ concentration (sample on $\mathrm{d}-11,-4$, and 7 ); US $=$ ultrasonography of the ovaries $(\mathrm{d}-11,-4,0$, and 7 ). 


\section{Ovulation to ECP, Pregnancy Success, and P/AI}

Cows with CL present on d 7 were defined as having ovulated to the ECP. Pregnancy per AI was calculated by dividing the number of pregnant cows at the pregnancy diagnosis 32 or $60 \mathrm{~d}$ after TAI by the total number of cows that received TAI. Pregnancy loss was calculated by dividing the number of cows that lost their pregnancy by the number of pregnant cows at the 32-d pregnancy diagnosis.

\section{Sample Collection}

Milk yield was measured daily between d 0 and 7 , and average daily production through this interval was used in the analysis. Rectal temperature was measured using a digital thermometer (Jumbo Display Lab Thermometer; DeltaTrak, Pleasanton, CA) at d 0 and 7. Elevated rectal temperature, as a surrogate for elevated body temperature, was defined as the average rectal temperature $\geq 39.1^{\circ} \mathrm{C}\left(<39.1^{\circ} \mathrm{C}=\right.$ no elevated body temperature), given that $39.1^{\circ} \mathrm{C}$ is considered a threshold for elevated body temperature in dairy cattle (Berman et al., 1985; West, 2003). Blood samples were collected on $\mathrm{d}-11(\mathrm{n}=1,574), \mathrm{d}-4(\mathrm{n}=1,548)$, and d $7(\mathrm{n}=1,516)$, by coccygeal venipuncture into $10-\mathrm{mL}$ blood collection tubes (Vacutainer, Becton Dickinson, Franklin Lakes, NJ). After blood collections, tubes were placed on ice immediately, maintained at $4^{\circ} \mathrm{C}$ for 12 $\mathrm{h}$, and centrifuged at $1,500 \times g$ for $15 \mathrm{~min}$ at room temperature for serum collection. Serum was stored at $-20^{\circ} \mathrm{C}$ for subsequent $\mathrm{P} 4$ analysis. Serum concentrations of $\mathrm{P} 4$ were analyzed using the Coat-A-Count solid phase ${ }^{125}$ I RIA kit (Diagnostic Products Inc., Los Angeles, CA) that had been previously validated in our laboratory (Santos and Vasconcelos, 2006). The intraassay coefficient of variation was $5.6 \%$, the inter-assay coefficient of variation was $10.2 \%$, and the assay sensitivity was $0.01 \mathrm{ng} / \mathrm{mL}$.

Receiver operating characteristic (ROC) curves were generated to determine the optimum concentration of $\mathrm{P} 4$ at $\mathrm{PGF}_{2 \alpha}$ that resulted in the highest sensitivity and specificity for prediction of $\mathrm{P} / \mathrm{AI}$ at $60 \mathrm{~d}$ in dairy cows. Thus, there were 2 classes of $\mathrm{P} 4$ concentration, based on the ROC curves, as above or below the calculated threshold of $3.66 \mathrm{ng} / \mathrm{mL}$.

\section{Statistical Analysis}

The experiment was analyzed as a completely randomized design. The binomial variables (elevated body temperature, class of circulating $\mathrm{P} 4$ concentration, ovulation to $\mathrm{GnRH}$, estrus detection, ovulation to ECP, double ovulation, $\mathrm{P} / \mathrm{AI}$ on $\mathrm{d} 32$ and 60 , and pregnancy losses from 32 to $60 \mathrm{~d}$ ) were analyzed using the GLIMMIX procedures of SAS (ver. 9.4, SAS Institute Inc., Cary, NC) with Satterthwaite approximation to determine the denominator degrees of freedom for tests of fixed effects, with farms as a random effect. Backward elimination was used for final model selection based on Wald statistics criterion when $P \leq 0.15$ for the following covariables (used as covariables if not the subject of the analysis): elevated body temperature, treatment, lactation number, DIM, BCS, and milk yield. Thus, independent statistical models were constructed to analyze each variable and the interaction between treatment and each variable (e.g., 8 different statistical models were used to construct Table 1).

The continuous discrete variables (i.e., lactation number, DIM, BCS, milk production, previous AI number, $\mathrm{P} 4$ concentrations at $\mathrm{d}-11,-4$ and 7 , and follicular diameter) were analyzed using the MIXED procedures of SAS. Backward elimination was also used for final model selection using the same potential covariables as used for binomial analyses.

The GLM procedure of SAS was used to determine whether each individual measurement influenced $\mathrm{P} / \mathrm{AI}$ linearly, quadratically, or cubically. When significant, the logistical regression models were fit by the method of maximum likelihood using PROC LOGISTIC of SAS to determine the intercept and slope(s) values according to maximum likelihood estimates from each significant continuous order effect, and the P/AI was determined. The logistical regression models were designed using the intercept and slope values on the following equation: Probability $=\left(\mathrm{e}^{\text {logistic equation }}\right) /\left(1+\mathrm{e}^{\text {logistic equation }}\right)$. Logistic curves were constructed using the minimum and maximum values detected for each individual measurement.

Covariables that were found to be not significant $(P$ $>0.15)$ were removed from the statistical model. The results are expressed as least squares means \pm standard errors of the mean (SEM) for continuous variables. In all analyses, differences were considered significant when $P \leq 0.05$, and differences between $P>0.05$ and $P \leq 0.10$ were considered tendencies.

\section{RESULTS}

No differences were detected between GnRH and 2CIDR treatments for lactation number $(2.45 \pm 0.36$ vs. $2.41 \pm 0.36 ; P=0.46)$, DIM $(187.8 \pm 13.5$ vs. 187.8 $\pm 13.5 ; P=0.99)$, BCS (2.92 \pm 0.03 vs. $2.95 \pm 0.03 ; P$ $=0.26)$, milk yield $(31.5 \pm 2.23$ vs. $31.3 \pm 2.23 \mathrm{~kg} / \mathrm{d}$; $P=0.63)$, presence of CL at start of protocol $\mathrm{d}-11$ [67.3\% (551/817) vs. $68.1 \%(560 / 821) ; P=0.74]$, or 
Table 1. Effects of different cow variables on pregnancy per AI (P/AI) using the d-60 pregnancy diagnosis (LSM; no./no. in parentheses)

\begin{tabular}{|c|c|c|c|c|c|}
\hline Variable & \multicolumn{2}{|c|}{ Protocol $^{1}$} & \multicolumn{3}{|c|}{$P$-value } \\
\hline \multicolumn{6}{|c|}{ Cow temperature $\left({ }^{\circ} \mathrm{C}\right)$} \\
\hline$\geq 39.1$ & $22.0(81 / 361)$ & $22.9(81 / 348)$ & & & \\
\hline \multicolumn{6}{|l|}{$\mathrm{BC} S$} \\
\hline$<2.75$ & $25.2(50 / 202)$ & $22.6(40 / 178)$ & 0.44 & 0.09 & 0.91 \\
\hline Primiparous & $34.1(74 / 224)$ & $35.1(79 / 233)$ & 0.62 & $<0.01$ & 0.89 \\
\hline Multiparous & $24.9(152 / 593)$ & $26.5(160 / 588)$ & & & \\
\hline \multicolumn{6}{|c|}{ Milk yield (kg/d) } \\
\hline$<30$ & $26.2(107 / 406)$ & $29.4(120 / 407)$ & 0.52 & 0.63 & 0.44 \\
\hline$\geq 30$ & $29.1(119 / 411)$ & $28.7(119 / 414)$ & & & \\
\hline \multicolumn{6}{|c|}{ Corpus luteum (CL) presence on d -11} \\
\hline No CL & $25.7(68 / 266)$ & $24.7(64 / 261)$ & 0.75 & 0.05 & 0.46 \\
\hline$<1.0$ & $24.3(72 / 297)$ & $28.2(83 / 294)$ & 0.52 & 0.16 & 0.30 \\
\hline$\geq 1.0$ & $30.0(148 / 492)$ & $29.1(143 / 491)$ & & & \\
\hline \multicolumn{6}{|c|}{ Estrus expression } \\
\hline No & $9.2(8 / 90)$ & $5.1(4 / 82)$ & 0.69 & $<0.01$ & 0.46 \\
\hline Yes & $30.9(216 / 701)$ & $32.1(228 / 712)$ & & & \\
\hline
\end{tabular}

${ }^{1}$ Protocols: $\mathrm{GnRH}=$ controlled internal drug-release insert (CIDR) $+2 \mathrm{mg}$ of estradiol benzoate $+100 \mu \mathrm{g}$ of $\mathrm{GnRH}$ on d $-11, \mathrm{PGF}_{2 \alpha}$ on d -4, CIDR withdrawal $+1.0 \mathrm{mg}$ of estradiol cypionate $(\mathrm{ECP})+\mathrm{PGF}_{2 \alpha}$ on $\mathrm{d}-2$, and timed $\mathrm{AI}$ on $\mathrm{d} 0 ; 2 \mathrm{CIDR}=2$ CIDR inserts $+2 \mathrm{mg}$ of estradiol benzoate on $\mathrm{d}-11, \mathrm{PGF}_{2 \alpha}$ on $\mathrm{d}-4$, CIDR withdrawal $+1.0 \mathrm{mg}$ of ECP $+\mathrm{PGF}_{2 \alpha}$ on $\mathrm{d}-2$, and timed $\mathrm{AI}$ on $\mathrm{d} 0$.

circulating $\mathrm{P} 4$ concentration at $\mathrm{d}-11(2.92 \pm 0.13$ vs. $2.97 \pm 0.13 \mathrm{ng} / \mathrm{mL} ; P=0.68)$.

\section{Overall Effects on P/AI}

The effects of treatment on $\mathrm{P} / \mathrm{AI}$ were stratified by elevated body temperature, BCS, parity, milk yield, CL at $\mathrm{d}-11$ and -4 , circulating $\mathrm{P} 4$ concentration on $\mathrm{d}$ -11 , and expression of estrus (Table 1). Treatment did not affect $\mathrm{P} / \mathrm{AI}$, using either $\mathrm{d}-32$ or d-60 pregnancy diagnosis, and there were no interactions between treatment and these various measures on P/AI. For example, the 2 treatment groups were not different for $\mathrm{P} /$ AI $(P>0.10)$ regardless of elevated body temperature, BCS, parity, milk yield, expression of estrus, presence or absence of a CL on $\mathrm{d}-11$ or -4 , or circulating P4 concentrations. There were effects or tendencies for effects of some of these variables to lower $\mathrm{P} / \mathrm{AI}$, such as cows with elevated body temperature $(P<0.01)$ or lower BCS $(<2.75 ; P=0.09)$ in multiparous compared with primiparous cows $(P<0.01)$, in cows without versus with a $\mathrm{CL}$ on $\mathrm{d}-11(P=0.05)$ and $\mathrm{d}-4(P$ $<0.01$ ), and in cows with no expression of estrus $(P$ $<0.01)$. In contrast, circulating $\mathrm{P} 4$ concentration at $\mathrm{d}$ $-11(P=0.16)$ and milk yield $(P=0.63)$ did not affect $\mathrm{P} / \mathrm{AI}$.

\section{Effects of Treatment and Elevated Body Temperature on Reproductive Measures}

Elevated body temperature was an important factor for altered reproductive physiology and decreased reproductive success in both treatments (Table 1). Table 2 shows the effect of elevated body temperature on various measures of reproductive physiology in cows treated with the 2 synchronization strategies. A greater proportion of $(P<0.01)$ cows in the $\mathrm{GnRH}$ treatment ovulated a follicle and had a new CL at $\mathrm{PGF}_{2 \alpha}$ compared with the 2CIDR treatment; however, elevated body temperature did not affect ovulation of a follicle on $\mathrm{d}-11(P=0.91)$. A greater $(P<0.01)$ proportion of cows in the GnRH treatment than in the 2CIDR treatment had CL at $\mathrm{PGF}_{2 \alpha}$. There also was a greater $(P=0.02)$ proportion (5.4 percentage points or $7.9 \%$ ) of cows with CL in cows without elevated body temperature $(68.3 \% ; 558 / 817)$ than in cows with elevated body temperature $(62.9 \% ; 446 / 709)$. Circulating $\mathrm{P} 4$ concentration was greater $(P=0.05)$ at the time of $\mathrm{PGF}_{2 \alpha}$ treatment $(\mathrm{d}-4)$ for cows in the $2 \mathrm{CIDR}$ group than in the GnRH group. Treatment did not alter expression of estrus at the end of the protocol $(P$ $=0.55$ ), although cows with elevated body temperature had reduced $(P<0.01 ; 4.7$ percentage points or 
Table 2. Effects of average body temperature of cows and treatment protocol ${ }^{1}$ on various measures of reproductive physiology (LSM; no./no. in parentheses)

\begin{tabular}{|c|c|c|c|c|c|}
\hline Variable and protocol & \multicolumn{2}{|c|}{ Cow temperature $\left({ }^{\circ} \mathrm{C}\right)$} & \multicolumn{3}{|c|}{$P$-value } \\
\hline \multicolumn{6}{|l|}{$\mathrm{P} 4 \mathrm{~d}-11(\mathrm{ng} / \mathrm{mL})^{2}$} \\
\hline $\mathrm{GnRH}$ & $2.93 \pm 0.15$ & $2.81 \pm 0.16$ & 0.34 & 0.57 & 0.91 \\
\hline \multirow{2}{*}{\multicolumn{6}{|c|}{ Ovulation of $\mathrm{d}-11$ follicle $\mathrm{e}^{2,3}$}} \\
\hline & & & & & \\
\hline $\mathrm{GnRH}$ & $42.6(175 / 402)$ & $40.7(153 / 361)$ & 0.91 & $<0.01$ & 0.42 \\
\hline \multicolumn{6}{|c|}{ Corpus luteum at $\mathrm{PGF}_{2 \alpha}{ }^{2}$} \\
\hline GnRH & $78.1(314 / 402)$ & $70.9(256 / 361)$ & 0.02 & $<0.01$ & 0.53 \\
\hline $2 \mathrm{CIDR}$ & $58.8(244 / 415)$ & $54.6(190 / 348)$ & & & \\
\hline \multicolumn{6}{|c|}{ Progesterone $(\mathrm{P} 4)$ at $\mathrm{d}-4(\mathrm{ng} / \mathrm{mL})^{2}$} \\
\hline GnRH & $4.12 \pm 0.14$ & $3.84 \pm 0.14$ & 0.09 & 0.05 & 0.67 \\
\hline 2CIDR & $4.34 \pm 0.13$ & $4.17 \pm 0.14$ & & & \\
\hline \multicolumn{6}{|l|}{ Estrus $^{2}$} \\
\hline GnRH & $89.9(365 / 402)$ & $85.6(312 / 361)$ & $<0.01$ & 0.55 & 0.84 \\
\hline GnRH & $3.65 \pm 0.15$ & $3.64 \pm 0.16$ & 0.69 & 0.03 & 0.61 \\
\hline 2CIDR & $3.43 \pm 0.15$ & $3.51 \pm 0.16$ & & & \\
\hline \multicolumn{6}{|l|}{ Double ovulation $^{4}$} \\
\hline $\mathrm{GnRH}$ & $21.7(70 / 367)$ & $25.8(77 / 318)$ & 0.08 & 0.40 & 0.98 \\
\hline $2 \mathrm{CIDR}$ & $19.8(65 / 367)$ & $23.9(67 / 306)$ & & & \\
\hline
\end{tabular}

${ }^{1}$ Protocols: $\mathrm{GnRH}=$ controlled internal drug-release insert (CIDR) $+2 \mathrm{mg}$ of estradiol benzoate $+100 \mu \mathrm{g}$ of $\mathrm{GnRH}$ on d $-11, \mathrm{PGF}_{2 \alpha}$ on d -4 , CIDR withdrawal $+1.0 \mathrm{mg}$ of estradiol cypionate $(\mathrm{ECP})+\mathrm{PGF}_{2 \alpha}$ on $\mathrm{d}-2$, and timed $\mathrm{AI}$ on $\mathrm{d} 0 ; 2 \mathrm{CIDR}=2 \mathrm{CIDR}$ inserts $+2 \mathrm{mg}$ of estradiol benzoate on $\mathrm{d}-11, \mathrm{PGF}_{2 \alpha}$ on $\mathrm{d}-4, \mathrm{CIDR}$ withdrawal $+1.0 \mathrm{mg}$ of $\mathrm{ECP}+\mathrm{PGF}_{2 \alpha}$ on $\mathrm{d}-2$, and timed $\mathrm{AI}$ on $\mathrm{d} 0$.

${ }^{2}$ All inseminated cows.

${ }^{3}$ Percentage of cows with a new corpus luteum on $\mathrm{d}-4$ that had a follicle $>8 \mathrm{~mm}$ on $\mathrm{d}-11$.

${ }^{4}$ Includes only cows that ovulated to ECP (visible CL on d 7).

$5.1 \%$ ) expression of estrus compared with cows without elevated body temperature $[86.7 \%(615 / 709)$ vs. $91.4 \%$ $(747 / 817)]$. The GnRH protocol resulted in larger follicles near TAI $(P<0.01)$ in cows without elevated body temperature. However, in cows with elevated body temperature, ovulatory follicle size did not differ with treatment protocol. Treatment with GnRH produced greater $(P=0.03)$ circulating $\mathrm{P} 4$ concentration $(3.54 \pm 0.15 \mathrm{ng} / \mathrm{mL})$ on $\mathrm{d} 7$ after TAI compared with 2CIDR protocol $(3.37 \pm 0.15 \mathrm{ng} / \mathrm{mL})$. Cows without elevated body temperature tended $(P=0.08)$ to have a lower incidence of double ovulation [18.7\% (135/734) vs. $23.8 \%(144 / 624)]$.

Ovulation near TAI tended to be greater $(P=0.09)$ in cows without elevated body temperature, but there was no effect of treatment protocol on ovulation near TAI (Table 3). Treatment did not affect $\mathrm{P} / \mathrm{AI}$ at the $32-\mathrm{d}$ or 60-d pregnancy diagnoses or pregnancy loss between 32 and $60 \mathrm{~d}$ of pregnancy. Cows without elevated body temperature during the protocol had greater $(P<0.01$; increased 11.3 percentage points or $49.6 \%) \mathrm{P} / \mathrm{AI}$ at 60 $\mathrm{d}$ [elevated body temperature $=22.8 \%(162 / 709)$, no elevated body temperature $34.1 \%(279 / 817) ; P<0.01]$ and tended to have lower pregnancy loss between $\mathrm{d} 32$ and 60 [elevated body temperature $=20.2 \%(41 / 203)$, no elevated body temperature $14.4 \%(47 / 326) ; P=$ $0.09]$ than cows with elevated body temperature.

\section{Effects of Ovulation at Beginning of Protocol on P/AI}

Ovulation to $\mathrm{GnRH}$ at the initiation of the protocol was $43.0 \%$ (328/763). Therefore, we performed another analysis evaluating cows that did or did not ovulate to GnRH (d -11) and further subdividing cows by elevated body temperature (Table 4). In cows without elevated body temperature, cows that ovulated to GnRH (GnRH-OV) tended to have greater ovulation near TAI $(P=0.09)$ compared with cows that did not ovulate to GnRH (GnRH-NOV) and cows treated with 2CIDR $(P=0.10)$. Further, in cows without elevated body temperature, the $\mathrm{P} / \mathrm{AI}$ at $60 \mathrm{~d}$ was greater for GnRH-OV $(P=0.01)$ than for GnRH-NOV and tended to be greater $(P=0.09)$ than the 2CIDR treatment. There was no effect on pregnancy loss between the treatments $(P=0.40)$. In cows with elevated body temperature, treatment did not affect ovulation to 
Table 3. Effects of treatments ${ }^{1}$ and cow temperature on ovulation to estradiol cypionate, pregnancy per AI (P/AI) at the 32-d or 60- $\mathrm{d}$ pregnancy diagnosis, and pregnancy loss from 32 to $60 \mathrm{~d}$ of gestation (LSM; no./no. in parentheses)

\begin{tabular}{|c|c|c|c|c|c|}
\hline Variable and protocol & \multicolumn{2}{|c|}{ Cow temperature $\left({ }^{\circ} \mathrm{C}\right)$} & \multicolumn{3}{|c|}{$P$-value } \\
\hline \multicolumn{6}{|l|}{ Ovulation near ECP ${ }^{2}$} \\
\hline 2CIDR & $86.2(359 / 415)$ & $84.8(298 / 348)$ & & & \\
\hline \multicolumn{6}{|c|}{$\mathrm{P} / \mathrm{AI}$ at $32 \mathrm{~d}$ for all cows ${ }^{3}$} \\
\hline GnRH & $39.7(162 / 402)$ & $26.2(98 / 361)$ & $<0.01$ & 0.64 & 0.42 \\
\hline \multicolumn{6}{|c|}{$\mathrm{P} / \mathrm{AI}$ at $60 \mathrm{~d}$ for all cows ${ }^{3}$} \\
\hline GnRH & $34.0(138 / 402)$ & $22.0(81 / 361)$ & $<0.01$ & 0.91 & 0.79 \\
\hline 2CIDR & $33.6(141 / 415)$ & $22.9(81 / 348)$ & & & \\
\hline \multicolumn{6}{|c|}{$\mathrm{P} / \mathrm{AI}$ at $60 \mathrm{~d}$ for synchronized cows ${ }^{4}$} \\
\hline $\mathrm{GnRH}$ & $38.9(138 / 355)$ & $26.6(81 / 304)$ & $<0.01$ & 0.86 & 0.98 \\
\hline 2CIDR & $39.3(141 / 359)$ & $27.2(81 / 298)$ & & & \\
\hline \multicolumn{6}{|c|}{ Pregnancy loss $(32-60 \mathrm{~d})^{4}$} \\
\hline $\mathrm{GnRH}$ & $14.8(24 / 162)$ & $17.4(17 / 98)$ & 0.09 & 0.48 & 0.34 \\
\hline
\end{tabular}

${ }^{1}$ Protocols: $\mathrm{GnRH}=$ controlled internal drug-release insert $(\mathrm{CIDR})+2 \mathrm{mg}$ of estradiol benzoate $+100 \mu \mathrm{g}$ of $\mathrm{GnRH}$ on $\mathrm{d}-11, \mathrm{PGF}_{2 \alpha}$ on $\mathrm{d}-4$, CIDR withdrawal $+1.0 \mathrm{mg}$ of estradiol cypionate $(\mathrm{ECP})+\mathrm{PGF}_{2 \alpha}$ on $\mathrm{d}-2$, and timed $\mathrm{AI}$ on $\mathrm{d} 0 ; 2 \mathrm{CIDR}=2 \mathrm{CIDR}$ inserts $+2 \mathrm{mg}$ of estradiol benzoate on $\mathrm{d}-11, \mathrm{PGF}_{2 \alpha}$ on $\mathrm{d}-4, \mathrm{CIDR}$ withdrawal $+1.0 \mathrm{mg}$ of ECP $+\mathrm{PGF}_{2 \alpha}$ on $\mathrm{d}-2$, and timed $\mathrm{AI}$ on $\mathrm{d} 0$.

${ }^{2}$ Based on presence of CL on d 7 .

${ }^{3}$ Includes all inseminated cows.

${ }^{4}$ Includes only cows that ovulated to ECP (visible corpus luteum on d 7).

ECP $(P=0.65)$ or $\mathrm{P} / \mathrm{AI}$ at $60 \mathrm{~d}(P=0.96)$; however, pregnancy loss was greater in 2 CIDR $(P=0.05)$ and in cows that ovulated to $\mathrm{GnRH}(P=0.04)$ compared with cows that did not ovulate to GnRH.

\section{Effects of $P 4$ at $P G F_{2 \alpha}$ on P/AI}

To determine the circulating P4 concentration on $\mathrm{d}$ -4 with the greatest accuracy for predicting pregnancy

Table 4. Ovulation near timed AI and pregnancy per AI (P/AI) at $60 \mathrm{~d}$ by body temperature of cows comparing treatment protocols ${ }^{1}$ with the GnRH protocol divided by whether cows ovulated to GnRH at the start of the protocol and cow temperature (LSM; no./no. in parentheses)

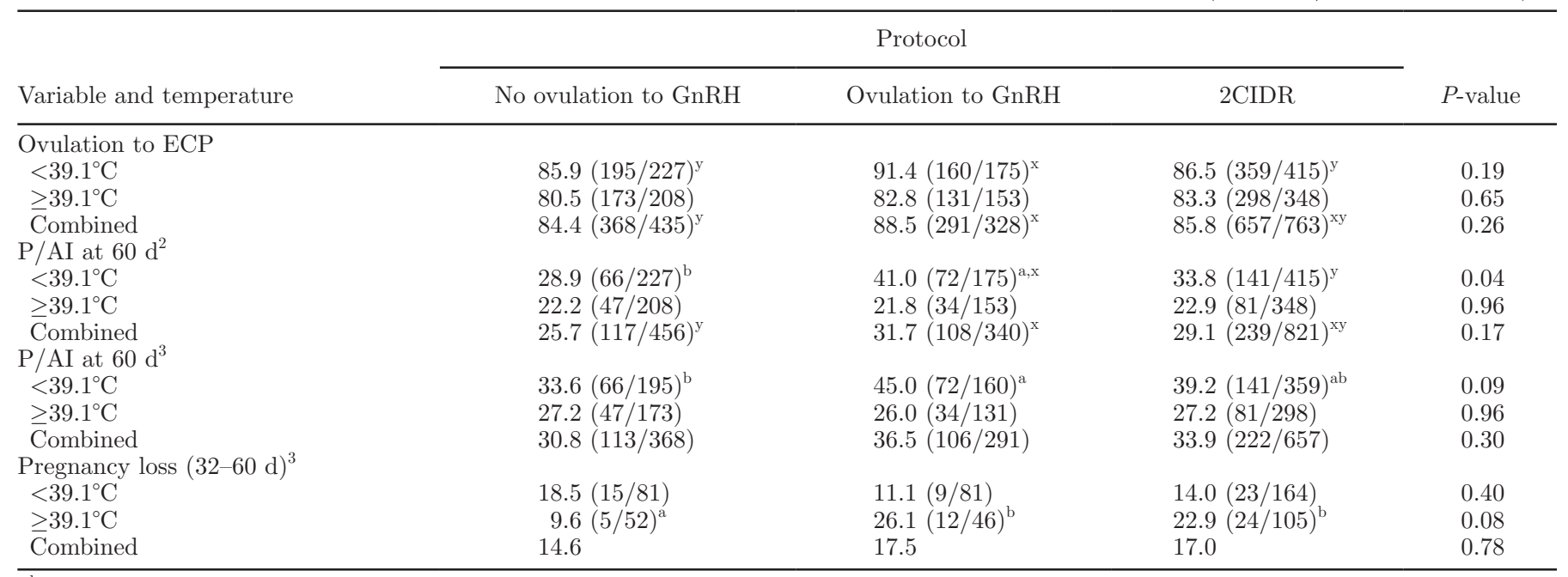

${ }_{\mathrm{a}, \mathrm{b}}$ Means in the same row without similar superscript letters differ at $P<0.05$.

${ }^{\mathrm{x}, \mathrm{y}}$ Means in the same row without similar superscript letters differ at $P<0.10$.

${ }^{1}$ Protocols: $\mathrm{GnRH}=$ controlled internal drug-release insert $(\mathrm{CIDR})+2 \mathrm{mg}$ of estradiol benzoate $+100 \mu \mathrm{g}$ of $\mathrm{GnRH}$ on $\mathrm{d}-11, \mathrm{PGF} \mathrm{F}_{2 \alpha}$ on -4 , CIDR withdrawal $+1.0 \mathrm{mg}$ of estradiol cypionate $(\mathrm{ECP})+\mathrm{PGF}_{2 \alpha}$ on $\mathrm{d}-2$, and timed $\mathrm{AI}$ on $\mathrm{d} 0 ; 2 \mathrm{CIDR}=2 \mathrm{CIDR}$ inserts $+2 \mathrm{mg}$ of estradiol benzoate on $\mathrm{d}-11, \mathrm{PGF}_{2 \alpha}$ on $\mathrm{d}-4$, CIDR withdrawal $+1.0 \mathrm{mg}$ of ECP $+\mathrm{PGF}_{2 \alpha}$ on $\mathrm{d}-2$, and timed $\mathrm{AI}$ on $\mathrm{d} 0$.

${ }^{2}$ Includes all inseminated cows.

${ }^{3}$ Includes only cows that ovulated to ECP (visible corpus luteum on d 7). 
Table 5. Effect of treatment protocol ${ }^{1}$ by progesterone $(\mathrm{P} 4)$ concentration at $\mathrm{PGF}_{2 \alpha}$ on pregnancy per AI (P/AI) at 60 d (LSM; no./no. in parentheses)

\begin{tabular}{|c|c|c|c|c|c|}
\hline \multirow[b]{2}{*}{ Variable and protocol } & \multicolumn{2}{|c|}{$\mathrm{P} 4$ at $\mathrm{PGF}_{2 \alpha}$} & \multirow[b]{2}{*}{$\mathrm{P} 4$} & \multicolumn{2}{|c|}{$P$-value } \\
\hline & $<3.66 \mathrm{ng} / \mathrm{mL}$ & $\geq 3.66 \mathrm{ng} / \mathrm{mL}$ & & Variable & Interaction \\
\hline GnRH & $29.8(56 / 186)$ & $38.7(77 / 200)$ & $<0.01$ & 0.93 & 0.16 \\
\hline $2 \mathrm{CIDR}$ & $24.9(51 / 202)$ & $43.0(89 / 207)$ & & & \\
\hline \multicolumn{6}{|c|}{ Cow temperature $\geq 39.1^{\circ} \mathrm{C}$} \\
\hline $\mathrm{GnRH}$ & $17.8(36 / 196)$ & $26.5(43 / 159)$ & $<0.01$ & 0.98 & 0.97 \\
\hline $\mathrm{GnRH}$ & $23.6(94 / 400)$ & $33.5(123 / 368)$ & $<0.01$ & 0.79 & 0.48 \\
\hline 2CIDR & $22.6(89 / 396)$ & $35.7(137 / 384)$ & & & \\
\hline \multicolumn{6}{|l|}{ Estrus } \\
\hline No & $5.6(5 / 92)$ & $9.2(7 / 77)$ & $<0.01$ & 0.03 & 0.25 \\
\hline Yes & $25.4(176 / 694)$ & $37.4(252 / 674)$ & & & \\
\hline \multicolumn{6}{|l|}{ Parity order } \\
\hline Primiparous & $28.8(53 / 195)$ & $41.7(91 / 227)$ & $<0.01$ & $<0.01$ & 0.66 \\
\hline
\end{tabular}

${ }^{1}$ Protocols: $\mathrm{GnRH}=$ controlled internal drug-release insert (CIDR) $+2 \mathrm{mg}$ of estradiol benzoate $+100 \mu \mathrm{g}$ of $\mathrm{GnRH}$ on $\mathrm{d}-11, \mathrm{PGF}_{2 \alpha}$ on $\mathrm{d}-4$, CIDR withdrawal $+1.0 \mathrm{mg}$ of estradiol cypionate $(\mathrm{ECP})+\mathrm{PGF}_{2 \alpha}$ on $\mathrm{d}-2$, and timed $\mathrm{AI}$ on $\mathrm{d} 0 ; 2 \mathrm{CIDR}=2 \mathrm{CIDR}$ inserts $+2 \mathrm{mg}$ of estradiol benzoate on $\mathrm{d}-11, \mathrm{PGF}_{2 \alpha}$ on $\mathrm{d}-4$, CIDR withdrawal $+1.0 \mathrm{mg}$ of $\mathrm{ECP}+\mathrm{PGF}_{2 \alpha}$ on $\mathrm{d}-2$, and timed $\mathrm{AI}$ on $\mathrm{d} 0$.

versus nonpregnancy on d 60 , ROC curves were generated. The circulating $\mathrm{P} 4$ concentration that resulted in the greatest combined sensitivity $(58.5 \%)$ and specificity $(55.8 \%)$ was $\geq 3.66 \mathrm{ng} / \mathrm{mL}(P<0.01)$. This indicates that $58.5 \%$ of the pregnant cows from the $60-\mathrm{d}$ pregnancy diagnosis had $\mathrm{P} 4 \geq 3.66 \mathrm{ng} / \mathrm{mL}$, whereas $55.8 \%$ of the nonpregnant cows had circulating $\mathrm{P} 4$ concentration $<3.66 \mathrm{ng} / \mathrm{mL}$. Cows with circulating P4 concentration $\geq 3.66 \mathrm{ng} / \mathrm{mL}$ had greater $\mathrm{P} / \mathrm{AI}$ at $60 \mathrm{~d}$ $(P<0.01)$, independent of elevated body temperature (Table 5). Cows that did not show estrus had reduced $\mathrm{P} / \mathrm{AI}$ compared with cows that showed estrus $(P<$ 0.03 ), independent of circulating $\mathrm{P} 4$ concentration at $\mathrm{PGF}_{2 \alpha}(P=0.25)$. We detected no interaction $(P=$ 0.66 ) between parity and circulating $\mathrm{P} 4$ concentration at $\mathrm{PGF}_{2 \alpha}$ on $\mathrm{P} / \mathrm{AI}$ but both $\mathrm{P} 4(P<0.01)$ and parity $(P<0.01)$ had independent effects on $\mathrm{P} / \mathrm{AI}$.

The 2 treatment groups were combined to analyze the effects of elevated body temperature with circulating $\mathrm{P} 4$ at time of $\mathrm{PGF}_{2 \alpha}$ on ovulation to the protocol and $\mathrm{P} / \mathrm{AI}$ (Table 6). Ovulation to ECP near the time of AI was only different when comparing cows with greater $\mathrm{P} 4$ concentrations without and with elevated body temperature $(88.3$ vs. $83.1 \% ; P=0.04)$. For $\mathrm{P} /$ $\mathrm{AI}$ at the 32 -d pregnancy diagnosis, there were effects of elevated body temperature in cows with either greater or lower concentrations of $\mathrm{P} 4$ at $\mathrm{PGF}_{2 \alpha}$ as well as effects of $\mathrm{P} 4$ in cows with or without elevated body temperature. Similarly, for P/AI at the $60 \mathrm{~d}$ pregnancy diagnosis, there were effects of elevated body temperature and circulating $\mathrm{P} 4$ in all combinations $(P<0.01)$. For pregnancy loss, the only effect was an increase in pregnancy loss due to elevated body temperature in cows with greater circulating $\mathrm{P} 4$ at $\mathrm{PGF}_{2 \alpha}$ (14.4 vs $23.7 \% ; P=0.04)$.

\section{Logistic Regression of P4 on P/AI and Pregnancy Loss}

Combining all data from both treatment groups using logistic regression demonstrated an overall effect $(P$ $<0.01$ ) of circulating $\mathrm{P} 4$ concentration at $\mathrm{PGF}_{2 \alpha}$ on $\mathrm{P} / \mathrm{AI}$ at the 32- and 60-d pregnancy diagnoses, with increases in circulating $\mathrm{P} 4$ associated with increases in $\mathrm{P} / \mathrm{AI}$. Surprisingly, pregnancy loss was also increased with increasing $\mathrm{P} 4$ at the time of $\mathrm{PGF}_{2 \alpha}(P=0.05)$ when all data were analyzed. Analysis of the 2 groups separately (Figure 2) demonstrated increased P/AI with increasing circulating $\mathrm{P} 4$ in both groups at the 32 -d pregnancy diagnosis $(P<0.01$ for 2CIDR and GnRH) and at the 60-d diagnosis (2CIDR, $P<0.01$; GnRH, $P=0.06)$. The effect of increasing $\mathrm{P} 4$ on pregnancy loss (Figure 2C) was only found in the GnRHtreated cows $(P=0.03)$, not in the 2CIDR cows $(P$ $=0.58)$. To further understand these effects, the cows were divided into 3 groups (Figure 3): 2CIDR, GnRHNOV, and GnRH-OV. At the 32-d pregnancy diagnosis (Figure 3A), increasing circulating $\mathrm{P} 4$ was associated with increasing $\mathrm{P} / \mathrm{AI}$ in $2 \mathrm{CIDR}(P<0.01)$ and $\mathrm{GnRH}-$ $\operatorname{NOV}(P=0.01)$, and tended to be associated $(P=$ 0.09 ) for GnRH-OV cows. At $60 \mathrm{~d}$ (Figure 3B), the effect of increasing $\mathrm{P} 4$ on $\mathrm{P} / \mathrm{AI}$ was clear in 2CIDR cows $(P<0.01)$ and less apparent in GnRH-NOV cows $(P=0.11)$, and there was no longer an association $(P$ $=0.62$ ) in GnRH-OV cows. For pregnancy loss (Figure $3 \mathrm{C}$ ), there was no effect of increasing $\mathrm{P} 4$ on pregnancy 
loss in 2CIDR $(P=0.58)$ or GnRH-NOV $(P=0.22)$ but increasing pregnancy loss was observed with increasing $\mathrm{P} 4$ in GnRH-OV cows $(P=0.05)$.

\section{Classification of Cows by Presence of CL at Beginning or End of Protocol}

Cows were classified by the presence or absence of CL on $\mathrm{d}-11$ and -4 and by treatment protocol (Table 7 ). Cows without CL on both days had reduced ovulation to ECP $(P<0.01)$ in both protocols. For both protocols, the circulating $\mathrm{P} 4$ concentration at $\mathrm{PGF}_{2 \alpha}(\mathrm{d}-4)$ was greater in cows with $\mathrm{CL}$ at both evaluations. Cows without CL at $\mathrm{d}-11$ and with CL at $\mathrm{d}-4$ had greater circulating $\mathrm{P} 4$ concentration at $\mathrm{PGF}_{2 \alpha}$ compared with cows without CL at both evaluations and cows with CL on $\mathrm{d}-11$ and without $\mathrm{CL}$ on $\mathrm{d}-4$. In all classes, the 2CIDR treatment had greater circulating P4 concentration at $\mathrm{PGF}_{2 \alpha}$ compared with the $\mathrm{GnRH}$ protocol. There was an effect of presence or absence of a CL at the 2 evaluations on $\mathrm{P} / \mathrm{AI}$ at the 32-d pregnancy diagnosis for both treatments. Thus, cows without a CL on $\mathrm{d}-11$ but with a CL on $\mathrm{d}-4$ and cows with CL at both evaluations had greater P/AI than the other 2 classes. The 2CIDR treatment tended to have greater $\mathrm{P} / \mathrm{AI}$ than $\mathrm{GnRH}$ in cows without $\mathrm{CL}$ at $\mathrm{d}-11$ and with CL at $\mathrm{d}-4$ and cows with CL at $\mathrm{d}-11$ and without $\mathrm{CL}$ at $\mathrm{d}-4$. Differences were less pronounced at the 60-d pregnancy diagnosis. Treatment with GnRH increased $(P<0.01)$ the percentage of cows in the 2 classes that had CL at $d-4$ compared with the 2 CIDR treatment.

\section{Effects of Ovulatory Follicle Diameter and $P 4$ at $d 7$ on P/AI}

We detected an effect of ovulatory follicle diameter on $\mathrm{P} / \mathrm{AI}$, although it was only observed in the GnRHOV cows (Figure 4). At the 32-d pregnancy diagnosis (Figure 4A), there was no effect of follicle diameter on $\mathrm{P} / \mathrm{AI}$ in 2 CIDR $(P=0.73)$ or GnRH-NOV $(P=0.76)$ cows but a clear increase in $\mathrm{P} / \mathrm{AI}$ with increasing ovulatory follicle diameter in GnRH-OV cows $(P<0.01)$. Similarly, at the 60-d diagnosis (Figure 3B), there was no effect of follicle diameter on $\mathrm{P} / \mathrm{AI}$ in 2CIDR $(P=$ $0.70)$ or GnRH-NOV $(P=0.65)$ cows, but a clear effect of follicle diameter on $\mathrm{P} / \mathrm{AI}$ in GnRH-OV cows $(P<$ $0.01)$. Pregnancy loss tended to decrease with increasing follicle diameter in GnRH-OV cows $(P=0.10)$ but not in 2CIDR $(P=0.86)$ or GnRH-NOV $(P=0.68)$ cows. There was no effect $(P=0.78)$ of $\mathrm{P} 4$ concentrations on $\mathrm{d} 7$ after $\mathrm{AI}$ on $\mathrm{P} / \mathrm{AI}$ when only cows that ovulated near TAI were included in the analyses.

\section{DISCUSSION}

This study compared 2 strategies to increase circulating $\mathrm{P} 4$ concentrations during growth of the preovulatory follicular wave to improve fertility of TAI protocols that used E2 and P4 to synchronize the estrous cycle of lactating dairy cows. The first strategy combined GnRH treatment with E2 at the beginning of the protocol (Pereira et al., 2015). The second strategy used 2 CIDR to increase P4 concentrations. Direct comparison of these 2 strategies in the present study did not

Table 6. Effect of body temperature of cow by progesterone $(\mathrm{P} 4)$ concentration at $\mathrm{PGF}_{2 \alpha}$ on pregnancy per $\mathrm{AI}(\mathrm{P} / \mathrm{AI})$ at $60 \mathrm{~d}$ (LSM; no./no. in parentheses)

\begin{tabular}{|c|c|c|c|}
\hline \multirow[b]{2}{*}{ Trait and temperature } & \multicolumn{2}{|c|}{$\mathrm{P} 4$ at $\mathrm{PGF}_{2 \alpha}$} & \multirow[b]{2}{*}{$P$-value } \\
\hline & $<3.66 \mathrm{ng} / \mathrm{mL}$ & $\geq 3.66 \mathrm{ng} / \mathrm{mL}$ & \\
\hline \multicolumn{4}{|c|}{ Ovulation to estradiol cypionate } \\
\hline$<39.1^{\circ} \mathrm{C}$ & $85.6(313 / 369)$ & $88.3(278 / 324)$ & 0.15 \\
\hline$\geq 39.1^{\circ} \mathrm{C}$ & $84.9(332 / 388)$ & $83.1(362 / 407)$ & 0.70 \\
\hline $\bar{P}$-value & 0.79 & 0.04 & \\
\hline \multicolumn{4}{|l|}{$\mathrm{P} / \mathrm{AI}$ at $32 \mathrm{~d}^{1}$} \\
\hline$<39.1^{\circ} \mathrm{C}$ & $36.3(81 / 313)$ & $53.5(114 / 278)$ & $<0.01$ \\
\hline$\geq 39.1^{\circ} \mathrm{C}$ & $25.8(122 / 332)$ & $41.1(194 / 362)$ & $<0.01$ \\
\hline $\bar{P}$-value & $<0.01$ & $<0.01$ & \\
\hline \multicolumn{4}{|l|}{$\mathrm{P} / \mathrm{AI}$ at $60 \mathrm{~d}^{1}$} \\
\hline$<39.1^{\circ} \mathrm{C}$ & $31.8(68 / 313)$ & $46.0(87 / 278)$ & $<0.01$ \\
\hline$\geq 39.1^{\circ} \mathrm{C}$ & $21.7(107 / 332)$ & $31.4(166 / 362)$ & $<0.01$ \\
\hline $\bar{P}$-value & $<0.01$ & $<0.01$ & \\
\hline \multicolumn{4}{|l|}{ Pregnancy loss ${ }^{1}$} \\
\hline$<39.1^{\circ} \mathrm{C}$ & $12.3(13 / 81)$ & $14.4(27 / 114)$ & 0.59 \\
\hline$\geq 39.1^{\circ} \mathrm{C}$ & $16.1(15 / 122)$ & $23.7(28 / 194)$ & 0.20 \\
\hline$P$-value & 0.45 & 0.04 & \\
\hline
\end{tabular}


demonstrate any differences in $\mathrm{P} / \mathrm{AI}$ at the 32 - or $60-\mathrm{d}$ pregnancy diagnoses or in pregnancy loss. Nevertheless, collection of specific physiological measurements in a large number of lactating cows during different seasons of the year allowed substantial insight into the physiological pathways that underlie fertility outcomes with these protocols. In a previous study (Pereira et al., 2015), the first strategy (GnRH addition) was found to increase $\mathrm{P} / \mathrm{AI}$ compared with the control protocol without $\mathrm{GnRH}(\mathrm{GnRH}+\mathrm{EB}=50.9 \%$ vs. $\mathrm{EB}=41.0 \%$ ). The second strategy (2 intravaginal P4 implants) has also shown an improvement in fertility in conjunction with a 5-d Cosynch protocol (Bisinotto et
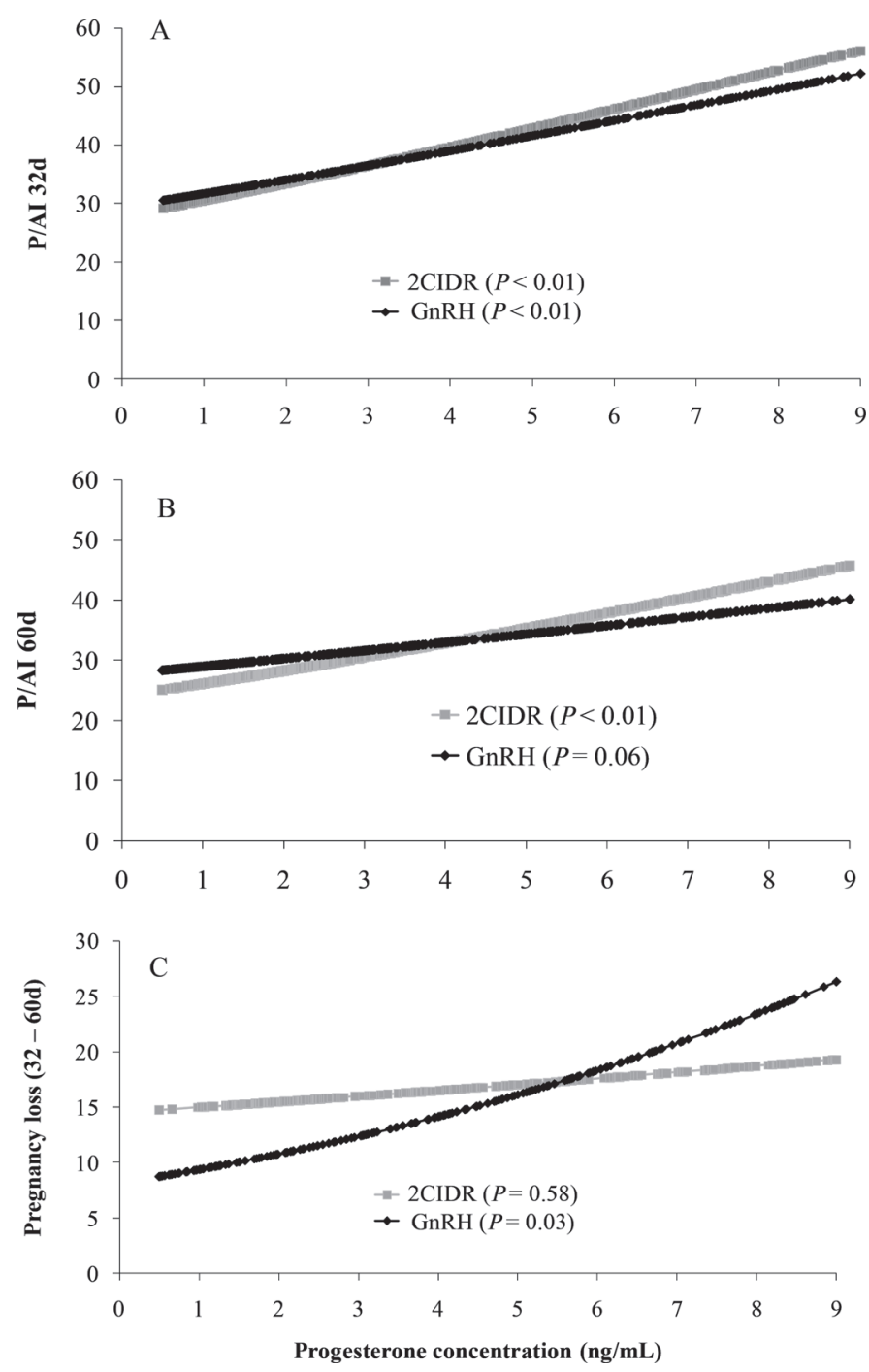

Figure 2. Logistic regression analysis of relationship between circulating progesterone $(\mathrm{P} 4)$ concentration at $\mathrm{PGF}_{2 \alpha}$ with pregnancies per $\mathrm{AI}(\mathrm{P} / \mathrm{AI})$ at $(\mathrm{A}) 32 \mathrm{~d}$ or $(\mathrm{B}) 60 \mathrm{~d}$, or $(\mathrm{C})$ for pregnancy loss for cows in the 2 treatment groups (2CIDR and GnRH; Figure 1). The lines represent the calculated logistic regression with symbols representing each cow that was part of the analysis.
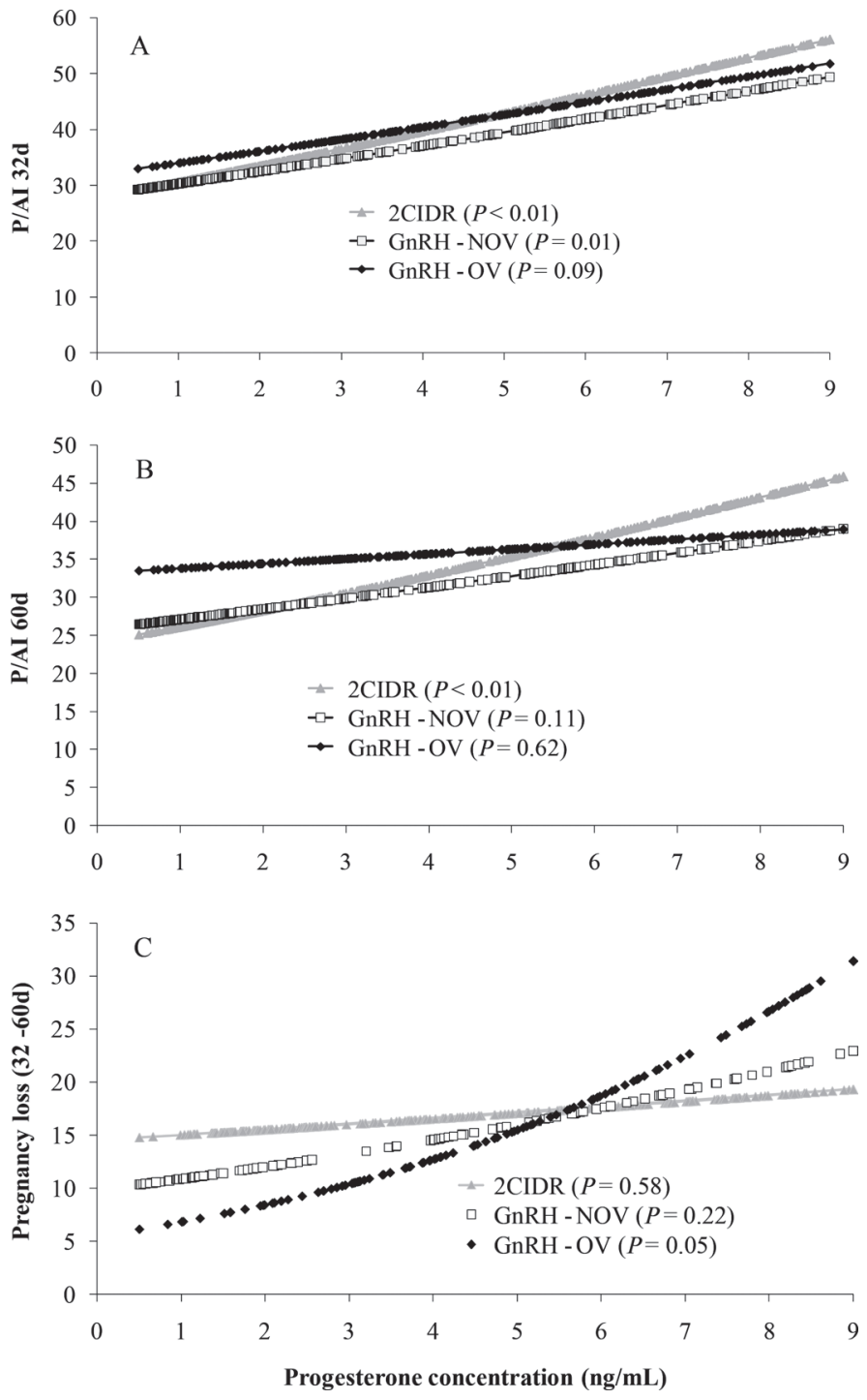

Figure 3. Logistic regression analysis of relationship between circulating progesterone $(\mathrm{P} 4)$ concentration at $\mathrm{PGF}_{2 \alpha}$ with pregnancies per AI (P/AI) at (A) $32 \mathrm{~d}$ or (B) $60 \mathrm{~d}$, or (C) for pregnancy loss for cows in 2 CIDR (Figure 1) or cows in GnRH group that ovulated ( $\mathrm{GnRH}-$ $\mathrm{OV}$ ) or did not ovulate (GnRH-NOV) to GnRH treatment. The lines represent the calculated logistic regression with symbols representing each cow that was part of the analysis.

al., 2013) and during an E2/P4 protocol (Pereira et al., 2017). Thus, both of these strategies enhanced fertility in previous studies but resulted in similar fertility in the present study.

Although there was no overall difference between protocols in $\mathrm{P} / \mathrm{AI}$, both protocols caused $>85 \%$ of cows to ovulate at the end of the protocol and $>35 \% \mathrm{P} / \mathrm{AI}$. Both protocols had similar $\mathrm{P} / \mathrm{AI}$ even when cows were divided by elevated body temperature, BCS, parity, milk yield, presence of a CL on $\mathrm{d}-11$ and -4 , circulating $\mathrm{P} 4$ concentration on $\mathrm{d}-11$ and -4 , or expression 
of estrus. Consistent with our expectations, both protocols resulted in high average circulating $\mathrm{P} 4$ concentration at $\mathrm{PGF}_{2 \alpha} \mathrm{d}-4(>3.95 \mathrm{ng} / \mathrm{mL})$, with the $\mathrm{GnRH}$ protocol having $48 \%$ (369/768) and 2CIDR having $49 \%$ $(384 / 780)$ of cows with circulating $\mathrm{P} 4 \geq 3.66 \mathrm{ng} / \mathrm{mL}$. In contrast, the $\mathrm{GnRH}$ protocol produced a greater proportion of cows with CL at $\mathrm{PGF}_{2 \alpha}$, whereas the $2 \mathrm{CIDR}$ treatment produced a greater elevation in circulating $\mathrm{P} 4$ concentration at the time of $\mathrm{PGF}_{2 \alpha}$ treatment.

Elevated body temperature was likely to have been caused by heat stress throughout this research, although disease or other cow circumstances can elevate body temperature. Basing the determination of elevated body temperature (heat stress) on measurements on multiple occasions in each cow should reduce errors due to technical imprecision in measurements of individual temperature but leave the possibility that in some cows other physiological or pathological conditions, rather than purely environmental conditions, could have led to an elevation in body temperature. This study found that certain physiological measurements were associated with greater fertility and most of these measures were reduced in cows with elevated body temperature: percentage of cows with CL at $\mathrm{PGF}_{2 \alpha}$ decreased $7.9 \%$, ovulatory follicle diameter decreased $0.51 \mathrm{~mm}$, ex- pression of estrus decreased $5.1 \%$, and ovulation near TAI decreased $2.8 \%$. These results are similar to our previous studies (Pereira et al., 2013, 2014, 2015). For example, elevated body temperature reduced follicular growth (Wilson et al., 1998), altered production of steroids by growing follicles (Wolfenson et al., 1995, 1997; Wilson et al., 1998), reduced expression of estrus (Younas et al., 1993), and reduced ovulation at the end of the protocol (Pereira et al., 2013). Each of these physiological changes could account for some of the decrease in fertility, although many studies have also demonstrated effects of elevated body temperature on oocyte health and fertilization (Sartori et al., 2002; Payton et al., 2004; Hackbart et al., 2010; Ferreira et al., 2011; Hooper et al., 2015), early embryonic development (Edwards and Hansen, 1997; Sakatani et al., 2012; Hansen, 2013), and maintenance of pregnancy (Vasconcelos et al., 2011b). This study directly used the temperature of each individual cow near the time of AI, based on the average of 2 independent observations, rather than only air temperature or temperature-humidity index, because cow temperature has been the most sensitive measure of negative effect of elevated body temperature on $\mathrm{P} / \mathrm{AI}$ in previous studies (Vasconcelos et al., 2011b; Pereira et al., 2015). Along with decreased P/

Table 7. Ovulation to estradiol cypionate (ECP), progesterone (P4) concentration, and pregnancy per AI (P/AI) at 32 and $60 \mathrm{~d}$ by presence or absence of corpus luteum (CL) at $\mathrm{d}-11$ and $\mathrm{d}-4$ by treatment ${ }^{1}$ (LSM; no./no. in parentheses)

\begin{tabular}{|c|c|c|c|c|c|}
\hline Variable and protocol & \multicolumn{4}{|c|}{ CL at $d-11 / d-4$} & $P$-value \\
\hline \multicolumn{6}{|l|}{ Ovulation to $\mathrm{ECP}^{2}$} \\
\hline 2CIDR & $76.1(116 / 152)^{\mathrm{a}}$ & $85.3(79 / 89)^{\mathrm{bc}}$ & $85.3(296 / 346)^{\mathrm{b}}$ & $93.6(166 / 177)^{\mathrm{c}}$ & $<0.01$ \\
\hline$P$-value & 0.64 & 0.23 & & & \\
\hline \multicolumn{6}{|l|}{$\mathrm{P} 4$ at $\mathrm{d}-4^{3}$} \\
\hline \multicolumn{6}{|c|}{$\mathrm{P} 4 \geq 3.66 \mathrm{ng} / \mathrm{mL}$ at $\mathrm{d}-4^{3,4}(\%)$} \\
\hline $\mathrm{GnRH}$ & $2.7(2 / 74)$ & $57.0(102 / 179)$ & $68.1(265 / 389)$ & $0.0(0 / 126)$ & \\
\hline 2CIDR & $7.0(11 / 157)$ & $76.9(70 / 91)$ & $80.7(284 / 352)$ & $10.6(19 / 180)$ & \\
\hline$P$-value & 0.19 & $<0.01$ & $<0.01$ & $<0.01$ & \\
\hline \multicolumn{6}{|l|}{$\mathrm{P} / \mathrm{AI}$ at $32 \mathrm{~d}^{3}$} \\
\hline GnRH & $23.1(18 / 77)^{\mathrm{a} *}$ & $34.6(64 / 183)^{\mathrm{b} *}$ & $38.9(160 / 407)^{\mathrm{b}}$ & $20.2(26 / 129)^{\mathrm{a}}$ & $<0.01$ \\
\hline$P$-value & 0.83 & 0.11 & 0.28 & 0.28 & \\
\hline \multicolumn{6}{|c|}{${ }^{\mathrm{a}-\mathrm{c}}$ Means in the same row with different superscript letters differ $(P<0.05)$ except if $* P=0.07$ (No/No vs. No/Yes). } \\
\hline \multicolumn{6}{|c|}{$\begin{array}{l}{ }^{1} \text { Protocols: } \mathrm{GnRH}=\text { controlled internal drug-release insert }(\mathrm{CIDR})+2 \mathrm{mg} \text { of estradiol benzoate }+100 \mu \mathrm{g} \text { of } \mathrm{GnRH} \text { on } \mathrm{d}-11, \mathrm{PGF} \mathrm{F}_{2 \alpha} \text { on } \mathrm{d}-4 \text {, } \\
\mathrm{CIDR} \text { withdrawal }+1.0 \mathrm{mg} \text { of estradiol cypionate }(\mathrm{ECP})+\mathrm{PGF}_{2 \alpha} \text { on } \mathrm{d}-2 \text {, and timed } \mathrm{AI} \text { on } \mathrm{d} 0 ; 2 \mathrm{CIDR}=2 \mathrm{CIDR} \text { inserts }+2 \mathrm{mg} \text { of estradiol } \\
\text { benzoate on } \mathrm{d}-11, \mathrm{PGF}_{2 \alpha} \text { on } \mathrm{d}-4, \mathrm{CIDR} \text { withdrawal }+1.0 \mathrm{mg} \text { of } \mathrm{ECP}+\mathrm{PGF}_{2 \alpha} \text { on } \mathrm{d}-2 \text {, and timed AI on d } 0 . \\
{ }^{2} \text { Based on presence of } \mathrm{CL} \text { on d } 7 \text {. } \\
{ }^{3} \text { All inseminated cows. }\end{array}$} \\
\hline
\end{tabular}


AI in cows with elevated body temperature, pregnancy loss between 32 and $60 \mathrm{~d}$ tended to be greater in cows with elevated body temperature in this study. Increased pregnancy loss has been previously reported (Pereira et al., 2013), in which cows with elevated body temperature had greater pregnancy losses $[23.8 \%(17 / 82)]$ than cows without elevated body temperature $[9.4 \%$ (20/241)]. Demetrio et al. (2007) also observed negative effects of elevated body temperature on pregnancy maintenance.

The use of ROC curves indicated that $\mathrm{P} 4$ of 3.66 $\mathrm{ng} / \mathrm{mL}$ at the time of $\mathrm{PGF}_{2 \alpha}$ was a threshold value
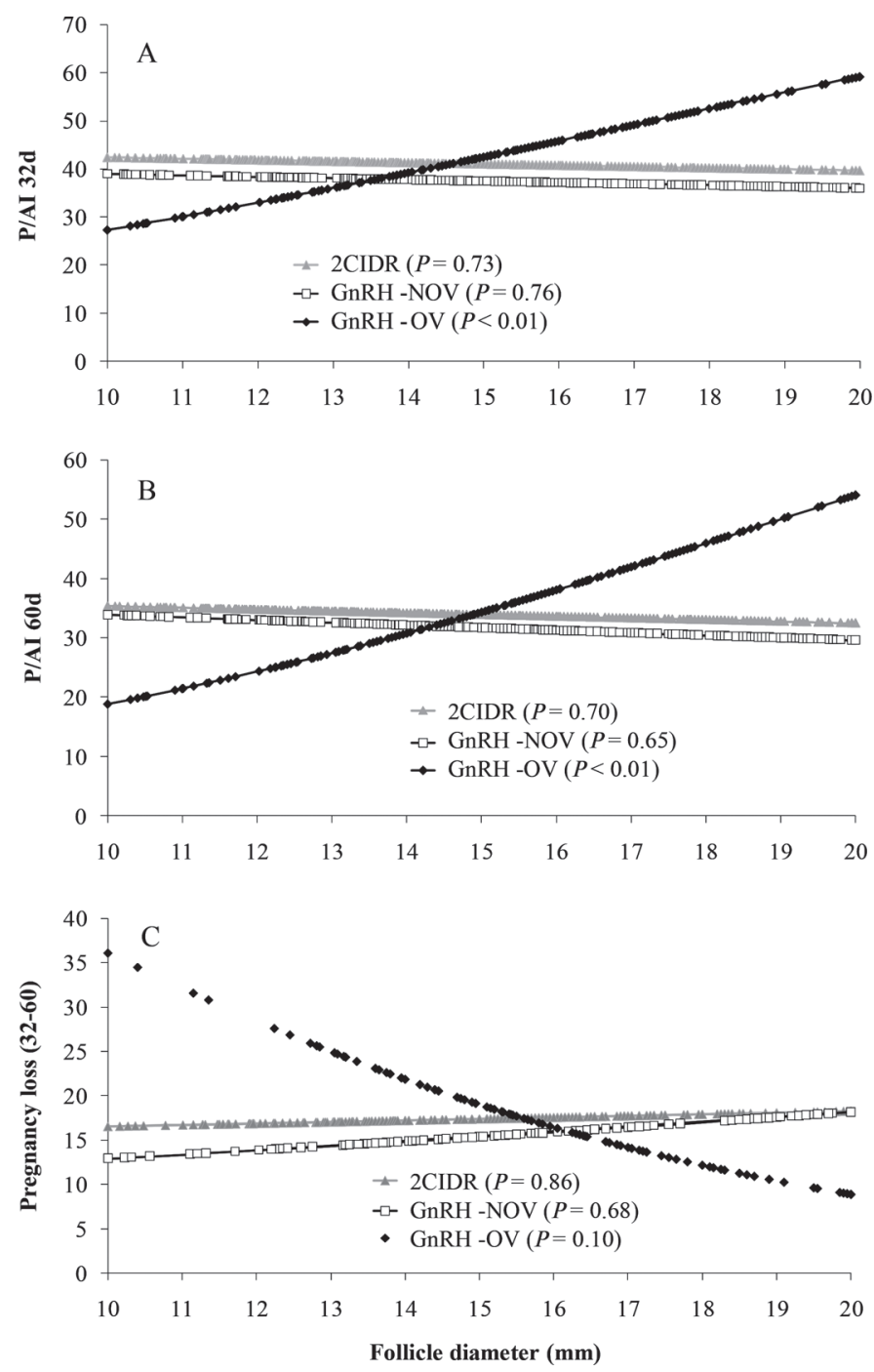

Figure 4. Logistic regression analysis of relationship between ovulatory follicle diameter with pregnancies per $\mathrm{AI}(\mathrm{P} / \mathrm{AI})$ at $(\mathrm{A}) 32 \mathrm{~d}$ or (B) $60 \mathrm{~d}$, or (C) for pregnancy loss for cows in 2CIDR (Figure 1) or cows in GnRH group that ovulated (GnRH-OV) or did not ovulate (GnRH-NOV) to GnRH treatment. The lines represent the calculated logistic regression with symbols representing each cow that was part of the analysis. that may be important in regulating fertility in lactating dairy cows, at least for cows in this study. Direct analysis of fertility results was consistent with this value as cows with circulating $\mathrm{P} 4$ concentration $\geq 3.66$ $\mathrm{ng} / \mathrm{mL}$ had a 13.2 -percentage-point greater P/AI (40.8 vs. 27.6) in cows without elevated body temperature and a 10.6-percentage-point greater $\mathrm{P} / \mathrm{AI}$ in cows with elevated body temperature (33.6 vs. 23.0). Thus, there were about $50 \%$ more pregnancies per AI in cows with high P4 $(13.2 / 27.6=47.8 \%$ or $11.6 / 23.0=50.4 \%)$ compared with cows with $\mathrm{P} 4<3.66 \mathrm{ng} / \mathrm{mL}$ at $\mathrm{PGF}_{2 \alpha}$, independent of elevated body temperature or treatment protocol. This is the first study that has attempted to define the critical circulating level of $\mathrm{P} 4$ associated with the TAI during an E2-/P4-based synchronization program in dairy cows. A previous study using an Ovsynch-type of TAI protocol calculated an optimal value of $3.78 \mathrm{ng} / \mathrm{mL}$, based on ROC curves (Ribeiro et al., 2012), which is very similar to the value that we obtained. Inclusion of a $\mathrm{GnRH}$ treatment at the start of the E2/P4 protocol in the GnRH treatment group increased the percentage of cows with $\mathrm{P} 4$ that exceeded the critical fertility value due to provision of an accessory CL during the protocol. Previous studies reported that E2/P4 protocols have reduced percentage of cows with $\mathrm{CL}$ at time of $\mathrm{PGF}_{2 \alpha}$ compared with $\mathrm{GnRH}$-based protocols $[5-\mathrm{d}$ Cosynch $=73.6 \%$ (597) vs. E2 $/ \mathrm{P} 4=$ 44.3\% (593); Pereira et al., 2013] and reduced circulating $\mathrm{P} 4$ concentration at $\mathrm{PGF}_{2 \alpha}$ (E2/P4: $2.29 \pm 0.15$ vs. GnRH: $2.89 \pm 0.15 \mathrm{ng} / \mathrm{mL}$; Vasconcelos et al., 2011a). Conversely, in the 2CIDR protocol there were more cows above this critical value for circulating $\mathrm{P} 4$, due to provision of exogenous $\mathrm{P} 4$, in spite of fewer cows with a $\mathrm{CL}$ at $\mathrm{PGF}_{2 \alpha}$. A previous study reported that treatment of cows without a CL at the initiation of a GnRH-based TAI protocol with 2 CIDR increased plasma $\mathrm{P} 4$ to 2.65 $\mathrm{ng} / \mathrm{mL}$ and restored fertility to a value that was similar to that of cows with a CL (no-CL control cows: $28.6 \%$, no-CL cows with 2CIDR: $43.7 \%$, cows with CL: $47.3 \%$; Bisinotto et al., 2013). All of these results support the idea that elevations in $\mathrm{P} 4$ during preovulatory follicle development increase fertility, with a value around 4 $\mathrm{ng} / \mathrm{mL}$ as a threshold value, based on ROC curves.

The effects of increased circulating P4 before AI have been linked to a reduced size of the preovulatory follicle, improved condition of the ovulated oocyte, and subsequent improvements in embryo quality during the first week of embryo development (Wiltbank et al., 2014). For example, Cerri et al. (2011b) collected embryos $6 \mathrm{~d}$ after AI from cows submitted to protocols with low or high $\mathrm{P} 4$, and reported no effect of $\mathrm{P} 4$ on fertilization rate but a tendency for greater embryo quality in cows receiving protocols with elevated $\mathrm{P} 4$ during preovulatory follicle development. Similarly, 
Rivera et al. (2011) reported an increased proportion of transferable embryos (78.6 vs. 55.9\%) when donors that were superovulated during the first follicular wave (low P4) received $2 \mathrm{P} 4$ implants during the protocol. However, in our results, the only group that demonstrated an effect of follicle diameter on fertility was the group that received $\mathrm{GnRH}$ and ovulated to the $\mathrm{GnRH}$ treatment and, paradoxically, $\mathrm{P} / \mathrm{AI}$ increased as follicle diameter increased in these cows. The increase in $\mathrm{P} /$ AI with increasing follicle diameter was clear at both the 32-d $(P<0.01)$ and $60-\mathrm{d}(P<0.01)$ pregnancy diagnoses, and pregnancy loss tended $(P=0.10)$ to decrease with increasing follicle diameter in cows that ovulated to $\mathrm{GnRH}$ but this relationship was not observed in cows that received 2 CIDR or that received GnRH but did not ovulate $(P>0.65$ for all logistic regressions). In a previous study, we found that initiation of a new follicular wave during the middle of a Ovsynch protocol by aspiration of the dominant follicle on d 3 or 4 after GnRH treatment resulted in ovulation of a much smaller follicle and greatly reduced fertility, perhaps due to reduced estradiol concentrations near AI or decreased circulating P4 after AI caused by the development of a smaller CL (Vasconcelos et al., 2001). Cows that ovulate to the GnRH will initiate a new follicular wave during the next day (Pursley et al., 1995), and the ovulatory follicle would be expected to have a large diameter by the end of the protocol, particularly with the 11-d protocol that was used in the present study. Thus, ovulation of a smaller follicle in cows that ovulated to GnRH is likely to be related to turnover of the dominant follicle before the end of the protocol, perhaps resulting in reduced fertility for the same reasons that were present in the previous manipulative study (Vasconcelos et al., 2001). It seems that extremely elevated circulating $\mathrm{P} 4$ would make it more likely for turnover of the follicular wave during the protocol, which may help explain the puzzling observation that increasing circulating $\mathrm{P} 4$ was associated with increased pregnancy loss but only in cows that ovulated to the GnRH treatment. Thus, initiation of a new follicular wave near the end of the protocol, as likely demonstrated by cows that ovulate small follicles in spite of ovulation to $\mathrm{GnRH}$ at the start of the protocol, may result in reduced expression of estrus that could reduce fertility (Pereira et al., 2016) or production of a smaller CL, resulting in reduced circulating $\mathrm{P} 4$ that may reduce fertility (Wiltbank et al., 2014). A shorter protocol may be more optimal when GnRH is used at the beginning of the protocol because loss of follicular dominance can occur in some animals before induction of ovulation when using a longer protocol.

In addition, previous studies have indicated that cows with low circulating $\mathrm{P} 4$ concentration during develop- ment of the ovulatory follicle are more likely to prematurely develop pathways leading to $\mathrm{PGF}_{2 \alpha}$ secretion by the endometrium, causing short luteal lifespan (Cerri et al., 2011a,b; Bisinotto et al., 2013). For example, Bisinotto et al., (2013) observed that the proportion of cows that were re-inseminated from d 5 to 17 after AI was greater $(P=0.02)$ for cows without CL at the beginning of the protocol than for cows with a CL or cows without a CL that were treated with 2CIDR during the TAI protocol. Nevertheless, in the study of Pereira et al. (2017), the authors did not observe an increase in short luteal phases and did not observe an effect of 2CIDR treatment on pregnancy in cows submitted to embryo transfer, suggesting that short luteal phases are unlikely to be an explanation for the greater fertility with increased P4 supplementation in cows that are already receiving a protocol that contains an CIDR. Sá Filho et al. (2009) reported that treatments with P4 (3 or 6 d) before induction of ovulation in anestrous Nelore (Bos indicus) cows increased the percentage of animals with a normal luteal lifespan. Thus, in protocols that use P4 implants during the protocol and end the protocol with ECP treatment, it seems unlikely, although not tested in this study, that short luteal phases are the primary mechanism underlying improvements in fertility with increased preovulatory $\mathrm{P} 4$. It seems more likely that changes in the ovulated oocyte, reproductive tract environment, or a combination of both processes underlie the improved fertility.

The evaluation of physiologic measures in over 1,500 cows allowed the interesting observations that the 2 treatments seem to have differing advantages and disadvantages. The 2 CIDR treatment consistently produced greater circulating $\mathrm{P} 4$ concentrations. For example, in cows with no $\mathrm{CL}$ at the time of $\mathrm{PGF}_{2 \alpha}(\mathrm{d}-4)$, circulating $\mathrm{P} 4$ was $0.89 \mathrm{ng} / \mathrm{mL}$ greater in 2CIDR than $\mathrm{GnRH}$ cows (2.19 vs. $1.30 \mathrm{ng} / \mathrm{mL}$ ), which translates to a $>60 \%$ increase in circulating $\mathrm{P} 4(0.89 / 1.30=68.5 \%)$. Cows with a CL on $\mathrm{d}-4$ had a similar absolute increase in $\mathrm{P} 4$ of $0.92 \mathrm{ng} / \mathrm{mL}(5.80$ vs. $4.88 \mathrm{ng} / \mathrm{mL})$ but the relative increase in $\mathrm{P} 4$ was $<20 \%(18.8 \%=0.92 / 4.88)$ for the 2CIDR cows compared with GnRH cows. Thus, 2CIDR should have an advantage over GnRH based on circulating $\mathrm{P} 4$. However, the GnRH treatment had the advantage of causing a much greater percentage of cows to ovulate at the beginning of the protocol (43.0 vs. $7.2 \%$ ); therefore, a much smaller percentage of cows lacked a CL at the time of $\mathrm{PGF}_{2 \alpha}$ (25.1 vs. $43.1 \%$ ). It should be noted that the proportion of cows with a CL at the time of $\mathrm{PGF}_{2 \alpha}$ was greater than the calculated proportion of cows that ovulated to the initial treatment of a protocol because some cows did not have an ovulatory-size follicle at the start of the protocol $(>8$ $\mathrm{mm}$ ) but had a CL at the time of $\mathrm{PGF}_{2 \alpha}$. We assumed 
that these cows had already ovulated at the beginning of the protocol, independent of the treatment. Thus, the overall percentage of cows in each group that were greater than the threshold value for $\mathrm{P} 4$ was similar [GnRH: 48.0\% (369/768) vs. 2CIDR: 49.2\% (384/780)]. However, these 2 strategies increased the percentage of cows above the threshold $\mathrm{P} 4$ by different routes: $\mathrm{GnRH}$ by increasing the percentage of cows with a $\mathrm{CL}$ on $\mathrm{d}-4$ and the 2 CIDR protocol by adding an extra $\sim 1 \mathrm{ng} / \mathrm{mL}$ of $\mathrm{P} 4$, which was necessary for some cows with a CL to exceed the $\mathrm{P} 4$ threshold. That the 2CIDR protocol had consistently greater $\mathrm{P} 4$ but not increased fertility is consistent with the concept that elevating $\mathrm{P} 4$ above the threshold value for fertility may be more important than the absolute magnitude of $\mathrm{P} 4$ during the protocol.

Despite the finding that treatment with 2 CIDR increased the circulating $\mathrm{P} 4$ concentration, in relation to the protocol with GnRH, there was no effect of treatment on $\mathrm{P} / \mathrm{AI}$. We speculate that the results in Table 7 may help to explain this dilemma. In cows with a newly formed CL (no/yes), the 2CIDR group had an increased percentage of cows above the threshold $\mathrm{P} 4$ $\left(\geq 3.66 \mathrm{ng} / \mathrm{mL}\right.$ at $\left.\mathrm{PGF}_{2 \alpha}\right)$ and this effect may underlie the tendency for increased $\mathrm{P} / \mathrm{AI}$ (28.9\% increase; $P=$ 0.09) compared with the GnRH treatment. Nevertheless, in cows without a CL (no/no), treatment with 2CIDR increased $\mathrm{P} 4$ but did not increase the percentage of cows above the threshold P4 and had no effects on fertility.

The results from the logistic regression analyses were intriguing and highlight some areas for future research. In particular, the increase in pregnancy loss with increasing $\mathrm{P} 4$ at the time of $\mathrm{PGF}_{2 \alpha}$ was surprising but may be useful in understanding pregnancy loss. This effect was only apparent in cows that ovulated at the beginning of the protocol; that is, those cows with a newer CL at the time of $\mathrm{PGF}_{2 \alpha}$. Cows with no CL at the beginning of the protocol were more likely to ovulate to the GnRH treatment and therefore only a single, younger CL was present at the end of the protocol. This suggests that an inadequate decrease in circulating P4 near the time of AI, due to incomplete regression of the younger CL, may explain this effect. In addition, this effect was primarily found in cows with elevated body temperature as shown in Table 6 in which pregnancy loss was greater in cows with elevated body temperature but only in cows with greater circulating P4. In a previous study done during summer with elevated body temperature, Pereira et al. (2013) reported that cows that ovulate to $\mathrm{GnRH}$ treatment at CIDR insertion in a 5-d Cosynch protocol tended to have greater pregnancy loss $(25.7 \%)$ than cows that did not ovulate to the GnRH injection at CIDR insertion (12.7\%). One additional insight from our logistic regression analyses was that cows that ovulated larger follicles at the end of the protocol had reduced pregnancy loss but, again, only cows that ovulated at the beginning of the protocol (Figure 4). These 2 phenomena may be related to lower P4 and greater circulating E2 near the time of AI producing a more favorable environment that may reduce subsequent pregnancy loss between 32 and $60 \mathrm{~d}$ of pregnancy. We discussed this intriguing concept in our previous studies in which we observed that cows that displayed estrus had reduced pregnancy loss either for cows bred to AI or by embryo transfer (Pereira et al., 2013, 2014, 2016). Thus, pregnancy loss probably involves uterine alterations related to the hormonal environment near AI.

\section{CONCLUSIONS}

We compared 2 protocols that were designed to increase circulating P4 during preovulatory follicle development. The 2 protocols provided similar results, with elevated body temperature having a major effect on fertility in both protocols. These results continue to provide support for the concept that cows with increased P4 during the preovulatory follicle wave have improved fertility, with the threshold $\mathrm{P} 4$ value calculated in this experiment being $3.66 \mathrm{ng} / \mathrm{mL}$. This study also provided information on elevated body temperature in dairy cows, with temperatures $>39.0^{\circ} \mathrm{C}$ being associated with lower $\mathrm{P} / \mathrm{AI}$ and higher pregnancy loss

\section{ACKNOWLEDGMENTS}

We acknowledge Fundação de Amparo a Pesquisa do Estado de São Paulo (FAPESP; São Paulo, Brazil) for supporting Marcos Henrique Colombo Pereira (grant number 2012/19059-2). Funding was also provided by the Wisconsin Experiment Station as Hatch Project WIS01240 to MCW and from the USDA National Institute of Food and Agriculture (Washington, DC; award number 2015-67015-23313).

\section{REFERENCES}

Araujo, R. R., O. J. Ginther, J. C. Ferreira, M. M. Palhao, M. A. Beg, and M. C. Wiltbank. 2009. Role of follicular estradiol-17beta in timing of luteolysis in heifers. Biol. Reprod. 81:426-437.

Berman, A., Y. Folman, M. Kaim, M. Mamen, Z. Herz, D. Wolfenson, A. Arieli, and Y. Graber. 1985. Upper critical temperatures and forced ventilation effects for high-yielding dairy cows in a subtropical climate. J. Dairy Sci. 68:1488-1495.

Bisinotto, R. S., R. C. Chebel, and J. E. Santos. 2010a. Follicular wave of the ovulatory follicle and not cyclic status influences fertility of dairy cows. J. Dairy Sci. 93:3578-3587.

Bisinotto, R. S., E. S. Ribeiro, F. S. Lima, N. Martinez, L. F. Greco, L. F. Barbosa, P. P. Bueno, L. F. Scagion, W. W. Thatcher, and J. E. Santos. 2013. Targeted progesterone supplementation improves fertility in lactating dairy cows without a corpus luteum at the 
initiation of the timed artificial insemination protocol. J. Dairy Sci. 96:2214-2225.

Bisinotto, R. S., E. S. Ribeiro, L. T. Martins, R. S. Marsola, L. F. Greco, M. G. Favoreto, C. A. Risco, W. W. Thatcher, and J. E. Santos. 2010b. Effect of interval between induction of ovulation and artificial insemination (AI) and supplemental progesterone for resynchronization on fertility of dairy cows subjected to a 5-d timed AI program. J. Dairy Sci. 93:5798-5808.

Cerri, R. L., R. C. Chebel, F. Rivera, C. D. Narciso, R. A. Oliveira, M. Amstalden, G. M. Baez-Sandoval, L. J. Oliveira, W. W. Thatcher, and J. E. Santos. 2011a. Concentration of progesterone during the development of the ovulatory follicle: II. Ovarian and uterine responses. J. Dairy Sci. 94:3352-3365.

Cerri, R. L., R. C. Chebel, F. Rivera, C. D. Narciso, R. A. Oliveira, W. W. Thatcher, and J. E. Santos. 2011b. Concentration of progesterone during the development of the ovulatory follicle: I. Ovarian and embryonic responses. J. Dairy Sci. 94:3342-3351.

Demetrio, D. G., R. M. Santos, C. G. Demetrio, and J. L. Vasconcelos. 2007. Factors affecting conception rates following artificial insemination or embryo transfer in lactating Holstein cows. J. Dairy Sci. 90:5073-5082.

Denicol, A. C., G. Lopes, L. G. Mendonça, F. A. Rivera, F. Guagnini, R. V. Perez, J. R. Lima, R. G. Bruno, J. E. Santos, and R. C. Chebel. 2012. Low progesterone concentration during the development of the first follicular wave reduces pregnancy per insemination of lactating dairy cows. J. Dairy Sci. 95:1794-1806.

Dirandeh, E., A. Rezaei Roodbari, and M. G. Colazo. 2015b. DoubleOvsynch, compared with presynch with or without GnRH, improves fertility in heat-stressed lactating dairy cows. Theriogenology 83:438-443.

Dirandeh, E. 2014. Starting Ovsynch protocol on day 6 of first postpartum estrous cycle increased fertility in dairy cows by affecting ovarian response during heat stress. Anim. Reprod. Sci. 149:135140.

Dirandeh, E., A. Rezaei Roodbari, M. Gholizadeh, H. Deldar, R. Masoumi, M. Kazemifard, and M. G. Colazo. 2015a. Administration of prostaglandin $\mathrm{F \alpha} 14 \mathrm{~d}$ before initiating a G6G or a $\mathrm{G} 7 \mathrm{G}$ timed artificial insemination protocol increased circulating progesterone prior to artificial insemination and reduced pregnancy loss in multiparous Holstein cows. J. Dairy Sci. 98:5414-5421.

Diskin, M. G., J. J. Murphy, and J. M. Sreenan. 2006. Embryo survival in dairy cows managed under pastoral conditions. Anim. Reprod. Sci. 96:297-311.

Edwards, J. L., and P. J. Hansen. 1997. Differential responses of bovine oocytes and preimplantation embryos to heat shock. Mol. Reprod. Dev. 46:138-145.

Erb, R. E., H. A. Garverick, R. D. Randel, B. L. Brown, and C. J. Callahan. 1976. Profiles of reproductive hormones associated with fertile and nonfertile inseminations of dairy cows. Theriogenology $5: 227-242$

FASS. 1999. Guide for the Care and Use of Agricultural Animals in Agricultural Research and Teaching. 1st ed. Federation of Animal Science Societies, Savoy, IL.

Ferreira, R. M., H. Ayres, M. R. Chiaratti, M. L. Ferraz, A. B. Araujo, C. A. Rodrigues, Y. F. Watanabe, A. A. Vireque, D. C. Joaquim, L. C. Smith, F. V. Meirelles, and P. S. Baruselli. 2011. The low fertility of repeat-breeder cows during summer heat stress is related to a low oocyte competence to develop into blastocysts. J. Dairy Sci. 94:2383-2392.

Folman, Y., M. Rosenber, Z. Herz, and M. Davidson. 1973. Relationship between plasma progesterone concentration and conception in postpartum dairy cows maintained on 2 levels of nutrition. J. Reprod. Fertil. 34:267-278.

Fonseca, F. A., J. H. Britt, B. T. Mcdaniel, J. C. Wilk, and A. H. Rakes. 1983. Reproductive traits of Holsteins and Jerseys-Effects of age, milk yield, and clinical abnormalities on involution of cervix and uterus, ovulation, estrous cycles, detection of estrus, conception rate, and days open. J. Dairy Sci. 66:1128-1147.

Fricke, P. M., D. Z. Caraviello, K. A. Weigel, and M. L. Welle. 2003. Fertility of dairy cows after resynchronization of ovulation at three intervals following first timed insemination. J. Dairy Sci. 86:39413950.

Giordano, J. O., J. N. Guenther, M. S. Ares, M. C. Wiltbank, and P. M. Fricke. 2010. Presynchronization with hCG $7 \mathrm{~d}$ before initiation of Resynch improves fertility similar to a double-Ovsynch Resynch protocol in lactating dairy cows. J. Dairy Sci. 93(E-Suppl. 1):219. (Abstr.)

Hackbart, K. S., R. M. Ferreira, A. A. Dietsche, M. T. Socha, R. D. Shaver, M. C. Wiltbank, and P. M. Fricke. 2010. Effect of dietary organic zinc, manganese, copper, and cobalt supplementation on milk production, follicular growth, embryo quality, and tissue mineral concentrations in dairy cows. J. Anim. Sci. 88:3856-3870.

Hansen, P. J. 2013. Cellular and molecular basis of therapies to ameliorate effects of heat stress on embryonic development in cattle. Anim. Reprod. 10:322-333.

Herlihy, M. M., J. O. Giordano, A. H. Souza, H. Ayres, R. M. Ferreira, A. Keskin, A. B. Nascimento, J. N. Guenther, J. M. Gaska, S. J. Kacuba, M. A. Crowe, S. T. Butler, and M. C. Wiltbank. 2012. Presynchronization with Double-Ovsynch improves fertility at first postpartum artificial insemination in lactating dairy cows. J. Dairy Sci. 95:7003-7014.

Hooper, L. M., R. R. Payton, L. A. Rispoli, A. M. Saxton, and J. L. Edwards. 2015. Impact of heat stress on germinal vesicle breakdown and lipolytic changes during in vitro maturation of bovine oocytes. J. Reprod. Dev. 61:459-464.

Martins, J. P., R. K. Policelli, L. M. Neuder, W. Raphael, and J. R. Pursley. 2011. Effects of cloprostenol sodium at final prostaglandin F2alpha of Ovsynch on complete luteolysis and pregnancy per artificial insemination in lactating dairy cows. J. Dairy Sci. 94:2815-2824

Meisterling, E. M., and R. A. Dailey. 1987. Use of concentrations of progesterone and estradiol-17-beta in milk in monitoring postpartum ovarian function in dairy cows. J. Dairy Sci. 70:2154-2161.

Monteiro, P. L. J., M. Borsato, F. L. M. Silva, A. B. Prata, M. C. Wiltbank, and R. Sartori. 2015. Increasing estradiol benzoate, pretreatment with gonadotropin-releasing hormone, and impediments for successful estradiol-based fixed-time artificial insemination protocols in dairy cattle. J. Dairy Sci. 98:3826-3839.

NRC. 2001. Nutrient Requirements of Dairy Cattle. 7th rev. ed. National Academies Press, Washington, DC.

Payton, R. R., R. Romar, P. Coy, A. M. Saxton, J. L. Lawrence, and J. L. Edwards. 2004. Susceptibility of bovine germinal vesicle-stage oocytes from antral follicles to direct effects of heat stress in vitro. Biol. Reprod. 71:1303-1308.

Pereira, M. H., A. D. Rodrigues, R. J. De Carvalho, M. C. Wiltbank, and J. L. Vasconcelos. 2014. Increasing length of an estradiol and progesterone timed artificial insemination protocol decreases pregnancy losses in lactating dairy cows. J. Dairy Sci. 97:1454-1464.

Pereira, M. H., A. D. Rodrigues, T. Martins, W. V. Oliveira, P. S. Silveira, M. C. Wiltbank, and J. L. Vasconcelos. 2013. Timed artificial insemination programs during the summer in lactating dairy cows: comparison of the 5-d Cosynch protocol with an estrogen/ progesterone-based protocol. J. Dairy Sci. 96:6904-6914.

Pereira, M. H., M. C. Wiltbank, L. F. Barbosa, W. M. Costa, M. A. Carvalho, and J. L. Vasconcelos. 2015. Effect of adding a gonadotropin-releasing-hormone treatment at the beginning and a second prostaglandin F2 $\alpha$ treatment at the end of an estradiol-based protocol for timed artificial insemination in lactating dairy cows during cool or hot seasons of the year. J. Dairy Sci. 98:947-959.

Pereira, M. H. C., C. P. Sanches Jr., T. G. Guida, M. C. Wiltbank, and J. L. M. Vasconcelos. 2017. Comparison of fertility following use of one versus two intravaginal progesterone inserts in dairy cows without a CL during a synchronization protocol before timed AI or timed embryo transfer. Theriogenology 89:72-78.

Pereira, M. H. C., M. C. Wiltbank, and J. L. M. Vasconcelos. 2016. Expression of estrus improves fertility and decreases pregnancy losses in lactating dairy cows that receive AI or embryo transfer. J. Dairy Sci. 99:2237-2247.

Pursley, J. R., M. O. Mee, and M. C. Wiltbank. 1995. Synchronization of ovulation in dairy cows using PGF2alpha and GnRH. Theriogenology 44:915-923. 
Ribeiro, E. S., R. S. Bisinotto, M. G. Favoreto, L. T. Martins, R. L. A. Cerri, F. T. Silvestre, L. F. Greco, W. W. Thatcher, and J. E. P. Santos. 2012. Fertility in dairy cows following presynchronization and administering twice the luteolytic dose of prostaglandin F-2 alpha as one or two injections in the 5-day timed artificial insemination protocol. Theriogenology 78:273-284.

Rivera, F. A., L. G. Mendonça, G. Lopes, J. E. Santos, R. V. Perez, M. Amstalden, A. Correa-Calderón, and R. C. Chebel. 2011. Reduced progesterone concentration during growth of the first follicular wave affects embryo quality but has no effect on embryo survival post transfer in lactating dairy cows. Reproduction 141:333-342.

Sá Filho, O. G., W. W. Thatcher, and J. L. M. Vasconcelos. 2009. Effect of progesterone and/or estradiol treatments prior to induction of ovulation on subsequent luteal lifespan in anestrous Nelore cows. Anim. Reprod. Sci. 112:95-106.

Sakatani, M., N. V. Alvarez, M. Takahashi, and P. J. Hansen. 2012 Consequences of physiological heat shock beginning at the zygote stage on embryonic development and expression of stress response genes in cattle. J. Dairy Sci. 95:3080-3091.

Sangsritavong, S., D. K. Combs, R. Sartori, L. E. Armentano, and M. C. Wiltbank. 2002. High feed intake increases liver blood flow and metabolism of progesterone and estradiol-17 beta in dairy cattle. J. Dairy Sci. 85:2831-2842.

Santos, R., and J. Vasconcelos. 2006. Concentrate intake and plasmatic progesterone concentration in Holstein cows. Arq. Bras. Med. Vet. Zootec. 58:1162-1167.

Sartori, R., G. J. M. Rosa, and M. C. Wiltbank. 2002. Ovarian structures and circulating steroids in heifers and lactating cows in summer and lactating and dry cows in winter. J. Dairy Sci. 85:28132822.

Silva, E., R. A. Sterry, D. Kolb, N. Mathialagan, M. F. McGrath, J. M. Ballam, and P. M. Fricke. 2009. Effect of interval to resynchronization of ovulation on fertility of lactating Holstein cows when using transrectal ultrasonography or a pregnancy-associated glycoprotein enzyme-linked immunosorbent assay to diagnose pregnancy status. J. Dairy Sci. 92:3643-3650.

Souza, A. H., H. Ayres, R. M. Ferreira, and M. C. Wiltbank. 2008. A new presynchronization system (Double-Ovsynch) increases fertility at first postpartum timed AI in lactating dairy cows. Theriogenology 70:208-215.

Sterry, R. A., M. L. Welle, and P. M. Fricke. 2006. Treatment with gonadotropin-releasing hormone after first timed artificial insemination improves fertility in noncycling lactating dairy cows. J. Dairy Sci. 89:4237-4245.

Stevenson, J. S., J. R. Pursley, H. A. Garverick, P. M. Fricke, D. J. Kesler, J. S. Ottobre, and M. C. Wiltbank. 2006. Treatment of cycling and noncycling lactating dairy cows with progesterone during Ovsynch. J. Dairy Sci. 89:2567-2578.

Stevenson, J. S., D. E. Tenhouse, R. L. Krisher, G. C. Lamb, J. E. Larson, C. R. Dahlen, J. R. Pursley, N. M. Bello, P. M. Fricke, M. C. Wiltbank, D. J. Brusveen, M. Burkhart, R. S. Youngquist, and H. A. Garverick. 2008. Detection of anovulation by heatmount detectors and transrectal ultrasonography before treatment with progesterone in a timed insemination protocol. J. Dairy Sci. 91:2901-2915.

Thatcher, W. W., M. Terqui, J. Thimonier, and P. Mauleon. 1986. Effect of estradiol-17beta on peripheral plasma concentration of 15-keto-13,14-dihydro PGF2alpha and luteolysis in cyclic cattle. Prostaglandins 31:745-756.

Vasconcelos, J. L., R. F. Cooke, D. T. Jardina, F. L. Aragon, M. B. Veras, S. Soriano, N. Sobreira, and A. B. Scarpa. 2011b. Associations among milk production and rectal temperature on pregnancy maintenance in lactating recipient dairy cows. Anim. Reprod. Sci. 127:140-147.

Vasconcelos, J. L. M., D. T. G. Jardina, O. G. Sa Filho, F. L. Aragon, and M. B. Veras. 2011a. Comparison of progesterone-based protocols with gonadotropin-releasing hormone or estradiol benzoate for timed artificial insemination or embryo transfer in lactating dairy cows. Theriogenology 75:1153-1160.

Vasconcelos, J. L. M., S. Sangsritavong, S. J. Tsai, and M. C. Wiltbank. 2003. Acute reduction in serum progesterone concentrations after feed intake in dairy cows. Theriogenology 60:795-807.

Vasconcelos, J. L. M., R. Sartori, H. N. Oliveira, J. G. Guenther, and M. C. Wiltbank. 2001. Reduction in size of the ovulatory follicle reduces subsequent luteal size and pregnancy rate. Theriogenology $56: 307-314$

Vasconcelos, J. L. M., R. W. Silcox, G. J. M. Rosa, J. R. Pursley, and M. C. Wiltbank. 1999. Synchronization rate, size of the ovulatory follicle, and pregnancy rate after synchronization of ovulation beginning on different days of the estrous cycle in lactating dairy cows. Theriogenology 52:1067-1078.

West, J. W. 2003. Effects of heat-stress on production in dairy cattle. J. Dairy Sci. 86:2131-2144.

Wildman, E. E., G. M. Jones, P. E. Wagner, R. L. Boman, H. F. Troutt, and T. N. Lesch. 1982. A dairy cow body condition scoring system and its relationship to selected production characteristics. J. Dairy Sci. 65:495-501.

Wilson, S. J., C. J. Kirby, A. T. Koenigsfeld, D. H. Keisler, and M. C Lucy. 1998. Effects of controlled heat stress on ovarian function of dairy cattle. 2. Heifers. J. Dairy Sci. 81:2132-2138.

Wiltbank, M., H. Lopez, R. Sartori, S. Sangsritavong, and A. Gumen. 2006. Changes in reproductive physiology of lactating dairy cows due to elevated steroid metabolism. Theriogenology 65:17-29.

Wiltbank, M. C., G. M. Baez, F. Cochrane, R. V. Barletta, C. R. Trayford, and R. T. Joseph. 2015. Effect of a second treatment with prostaglandin F2 $\alpha$ during the Ovsynch protocol on luteolysis and pregnancy in dairy cows. J. Dairy Sci. 98:8644-8654.

Wiltbank, M. C., and J. R. Pursley. 2014. The cow as an induced ovulator: Timed AI after synchronization of ovulation. Theriogenology $81: 170-185$

Wiltbank, M. C., A. H. Souza, P. D. Carvalho, A. P. Cunha, J. O. Giordano, P. M. Fricke, G. M. Baez, and M. G. Diskin. 2014 Physiological and practical effects of progesterone on reproduction in dairy cattle. Animal 8:70-81.

Wolfenson, D., B. J. Lew, W. W. Thatcher, Y. Graber, and R. Meidan. 1997. Seasonal and acute heat stress effects on steroid production by dominant follicles in cows. Anim. Reprod. Sci. 47:9-19.

Wolfenson, D., W. W. Thatcher, L. Badinga, J. D. Savio, R. Meidan, B. J. Lew, R. Braw-Tal, and A. Berman. 1995. Effect of heat stress on follicular development during the estrous cycle in lactating dairy cattle. Biol. Reprod. 52:1106-1113.

Younas, M., J. W. Fuquay, A. E. Smith, and A. B. Moore. 1993. Estrous and endocrine responses of lactating Holsteins to forced ventilation during summer. J. Dairy Sci. 76:430-436. 